COMPARATIVE EVALUATION OF AMBIENT FINE PARTICULATE MATTER (PM2.5) DATA OBTAINED FROM URBAN AND RURAL MONITORING SITES ALONG THE UPPER OHIO RIVER VALLEY

\author{
SEMI-ANNUAL \\ TECHNICAL PROGRESS REPORT \\ OCTOBER 1, 2003 THROUGH MARCH 31, 2004
}

Submitted to:

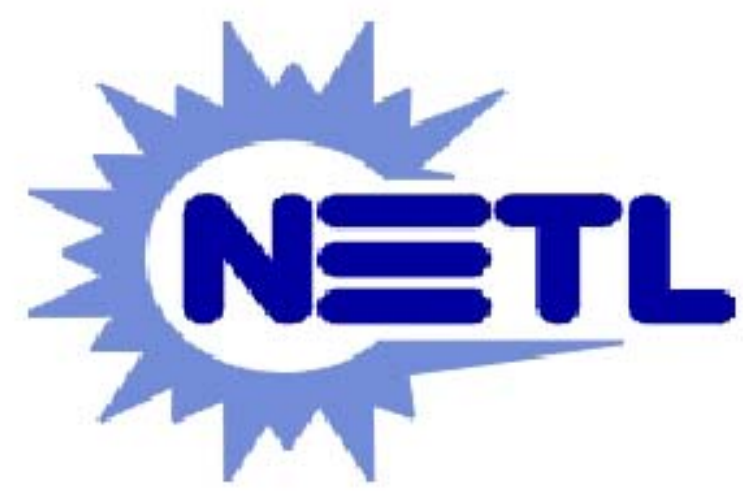

U. S. Department of Energy

National Energy Technology Laboratory Pittsburgh, PA 15236

DOE AWARD NUMBER: DE-AC26-98FT40456 


\section{COMPARATIVE EVALUATION OF AMBIENT FINE PARTICULATE MATTER (PM2.5) DATA OBTAINED FROM URBAN AND RURAL MONITORING SITES ALONG THE UPPER OHIO RIVER VALLEY Semi-Annual Technical Progress Report}

REPORT PERIOD START DATE:

REPORT PERIOD END DATE:

REPORT NO.:

PRINCIPAL AUTHORS:

DATE REPORT ISSUED:

DOE AWARD NUMBER:

CONTRACTOR:

SUBCONTRACTORS:

ATS PROJECT NO:
October 1, 2003

March 31, 2004

09

Robinson P. Khosah, Ph.D. John P. Shimshock, Ph.D.

Jerry L. Penland

Advanced Technology Systems, Inc.

April 15, 2004

DE-AC26-98FT40456

Advanced Technology Systems, Inc.

639 Alpha Drive - RIDC Park

Pittsburgh, PA 15238-2819

Ohio University

E317 Grover

Athens, $\mathrm{OH} 45701$

Desert Research Institute

2215 Raggio Parkway

Reno, NV 89512

98-839-P 


\section{DISCLAIMER}

This report was prepared as an account of work sponsored by an agency of the United States Government. Neither the United States Government nor any agency thereof, nor any of their employees, makes any warranty, expressed or implied, or assumes any legal liability or responsibility for the accuracy, completeness, or usefulness of any information, apparatus, product, or process disclosed, or represents that its use would not infringe privately owned rights. Reference herein to any specific commercial product, process, or service by trade name, trademark, manufacturer, or otherwise does not necessarily constitute or imply its endorsement, recommendation, or favoring by the United States Government or any agency thereof. The views and opinions of authors expressed herein do not necessarily state or reflect those of the United States Government or any agency thereof. 


\section{ABSTRACT}

Advanced Technology Systems, Inc. (ATS), with Desert Research Institute (DRI) and Ohio University as subcontractors, was contracted by the NETL in September 1998 to manage the Upper Ohio River Valley Project (UORVP), which included the establishment and operation of four ambient air monitoring sites located in the Upper Ohio River Valley (UORV). Two urban and two rural monitoring sites were included in the UORVP. The four sites selected for the UOVRP were collocated at existing local and/or state air quality monitoring stations. The goal of the UORVP was to characterize the nature and composition of $\mathrm{PM}_{2.5}$ and its precursor gases. In the process, the objectives of the UORVP were to examine the ambient air concentrations of $\mathrm{PM}_{2.5}$ as compared with the promulgated $\mathrm{PM}_{2.5}$ standards, the geographical, seasonal and temporal variations of ambient air concentrations of $\mathrm{PM}_{2.5}$, the primary chemical constituents of $\mathrm{PM}_{2.5}$, and the correlations between ambient air concentrations of $\mathrm{PM}_{2.5}$ and its precursor gases, other gaseous pollutants and meteorological parameters. A variety of meteorological and pollutant measurement devices, including several different $\mathrm{PM}_{2.5}$ samplers that provided either real-time or integrated concentration data, were deployed at the monitoring sites. The frequency of integrated sampling varied throughout the UORVP study period and was as follows:

- "Intensive" sampling periods were defined as periods in which samples were collected on a relatively frequent basis (ranged from 6-hour integrated samples collected round-theclock to one 24-hour integrated sample collected every third day).

- "Background" sampling periods were defined as periods in which 24-hour integrated samples were collected every third or sixth day.

Sampling activities for the UORVP were initiated in February 1999 and concluded in February 2003. This semi-annual Technical Progress Report summarizes the data analyses and interpretations conducted during the period from October 2003 through March 2004. This report was organized in accordance with the Guidelines for Organization of Technical Reports (September 2003). 


\section{TABLE OF CONTENTS}

DISCLAIMER

Page No.

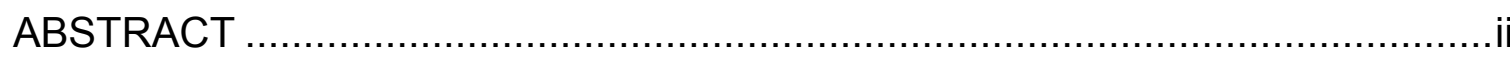

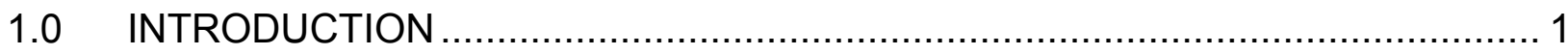

$1.1 \quad$ Background and Summary of the Scope of Work .............................. 1

1.2 Project Goal and Objectives ......................................................... 2

1.3 Project Organization .................................................................. 3

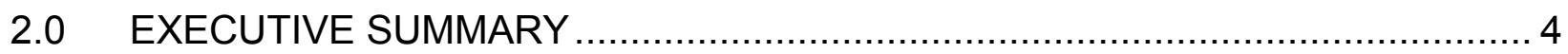

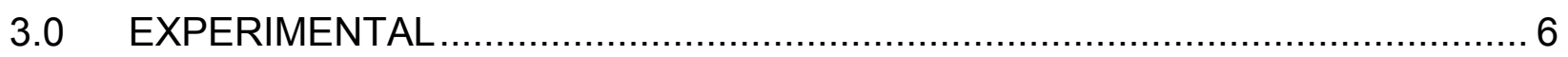

3.1 Ambient Air Monitoring Site Locations ............................................. 6

3.2 Ambient Air Parameters and Sampling / Analytical Methodologies ........... 7

3.3 Sampling Schedule .................................................................... 7

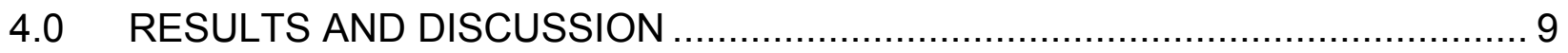

4.1 Current Data Status for the UORVP Sites ........................................ 9

4.2 Data Collected During the Background Sampling Periods ...................... 10

4.2.1 $\mathrm{PM}_{2.5}$ Mass Concentrations - Site Comparisons -

DRI Sampling Equipment....................................................... 10

4.2.2 $\mathrm{PM}_{10}$ Mass Concentrations - Site Comparisons -

DRI Sampling Equipment .................................................... 12

4.2.3 Comparison of $\mathrm{PM}_{2.5}$ with $\mathrm{PM}_{10}$ Mass Concentrations -

DRI Sampling Equipment.

4.2.4 Comparison of $\mathrm{PM}_{2.5}$ Mass Concentrations - DRI Sampling

Equipment with $\mathrm{PM}_{2.5}$ Mass Concentrations - FRM Sampling

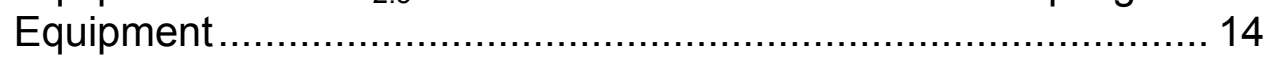

4.3 Data Collected During the Intensive Sampling Periods ........................ 15

4.3.1 Diurnal Variations of $L W P_{2.5}$ and $\mathrm{PM}_{10}$ Mass Concentrations -

DRI Sampling Equipment..................................................... 15

4.3.2 Seasonal Variations of $\mathrm{PM}_{2.5}$ Mass Concentrations -

Site Comparisons - DRI Sampling Equipment ............................ 16

4.3.3 Seasonal Variations of $\mathrm{PM}_{10}$ Mass Concentrations -

Site Comparisons - DRI Sampling Equipment

4.3.4 Presence of Trace Elements in $\mathrm{PM}_{2.5}$ and $\mathrm{PM}_{10}$ Samples -

DRI Sampling Equipment - Site and Particle Size Comparisons.. 19 


\section{TABLE OF CONTENTS (continued)}

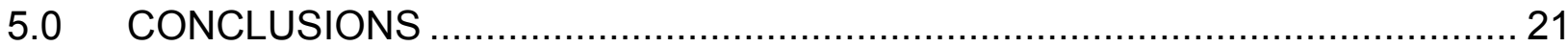

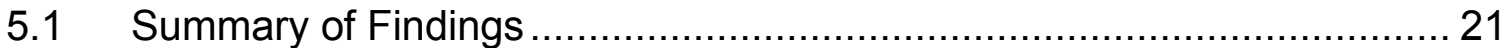

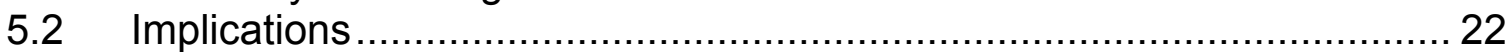

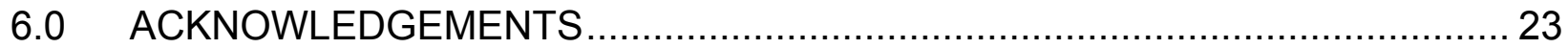

\section{LIST OF FIGURES}

Figure 1 Location of the UORVP Air Monitoring Sites and Neighboring Coal-Fired Electric Utility Plants

Figure 2 UORVP Organization Chart

\section{LIST OF TABLES}

Table 1 Summary of the Ambient Air Parameters and the Associated Measurement Techniques Deployed at Each of the Four UORVP Sites

Table 2 Integrated $\mathrm{PM}_{2.5}$ Samplers - Sampling and Analysis Log

Table 3 Integrated $\mathrm{PM}_{10}$ Samplers - Sampling and Analysis Log

Table 4 Integrated Nitric Acid $\left(\mathrm{HNO}_{3}\right)$ Gas Sampler - Sampling and Analysis Log

Table 5

Table 6

Table 7

Table 8

Table 9 Integrated Ammonia $\left(\mathrm{NH}_{3}\right)$ Gas Sampler - Sampling and Analysis Log Integrated $\mathrm{PM}_{2.5}$ Particle Size Sampler - Sampling and Analysis Log Current Data Status Summary for the Athens (AT) Site Current Data Status Summary for the Holbrook (HB) Site Current Data Status Summary for the Lawrenceville (LW) Site

Table 10 Current Data Status Summary for the Morgantown (MO) Site

\section{APPENDICES}

Appendix A Digital Images of the UORVP Air Monitoring Sites 


\subsection{INTRODUCTION}

\subsection{Background and Summary of the Scope of Work}

In July 1997, the U.S. Environmental Protection Agency (U.S. EPA) promulgated updates to the National Ambient Air Quality Standards for particulate matter (please refer to the following reference link: http://www.epa.gov/ttn/amtic/files/cfr/recent/pmnaaqs.pdf). The updates included (i) revisions to the existing daily ambient air standard for $\mathrm{PM}_{10}$ and (ii) establishing new daily and annual ambient air standards for $\mathrm{PM}_{2.5}$ (herein after referred as fine particulate matter). Investigative studies conducted prior to July 1997 suggested that the U.S. EPA would eventually classify many areas of the U.S. as non-attainment areas with regards to the new $\mathrm{PM}_{2.5}$ standards. The U.S. EPA mandates that state and local environmental regulatory agencies, in cooperation with industries located within non-attainment areas, develop state implementation plans (SIPs) for these areas. The SIPs include procedures and practices that will ultimately result with the non-attainment area demonstrating attainment with the pertinent ambient air standard. Historically, the SIPs often mandate reducing air emissions of the criteria pollutant and/or its precursor gases from stationary, mobile and area sources. In response to the new $\mathrm{PM}_{2.5}$ ambient air standards, the U.S. Department of Energy's National Energy Technology Laboratory (NETL), in cooperation with key stakeholders including the U.S. EPA, local and state environmental regulatory agencies, industry and academia, elected to fund ambient air monitoring research programs located throughout the U.S. to investigate (i) the nature and composition of $\mathrm{PM}_{2.5}$ and its precursor gases (e.g., sulfur dioxide [ $\mathrm{SO}_{2}$ ], nitrogen oxides [ $\mathrm{NO}_{\mathrm{X}}$ ]) and (ii) the relationship between emissions from coal-fired electric utilities and ambient air quality. One of the research programs is the Upper Ohio River Valley Project (UOVRP), which included the establishment and operation of ambient air monitoring sites located in the Upper Ohio River Valley (UORV). The UORV was chosen for extensive fine particulate research since it is representative of areas in the eastern half of the continental United States that are not well characterized in terms of the ambient air concentrations and chemical composition of $\mathrm{PM}_{2.5}$ but have a high density of coal-fired electric utility, heavy industry (e.g., coke and steel making), light industry and transportation emission sources. The UORV is also in the center of the ozone transport region, which provides a platform to study interstate pollution transport issues.

The location of the two urban and two rural ambient air monitoring sites included in the UORVP along with neighboring coal-fired electric utility plants are presented in Figure 1. The four sites selected for the UOVRP were collocated at existing local and/or state air quality monitoring stations. The sites were as follows:

U.S. DOE NETL 40456R09

ATS Project No. 98-839-P 


\begin{tabular}{|l|l|l|l|}
\hline SITE NAME & \multicolumn{1}{|c|}{ LOCATION } & $\begin{array}{c}\text { SITE } \\
\text { TYPE }\end{array}$ & \multicolumn{1}{|c|}{$\begin{array}{c}\text { COOPERATING REGULATORY } \\
\text { AGENCY }\end{array}$} \\
\hline Athens (AT) & Athens, OH & Rural & Ohio EPA (OH EPA) \\
\hline Holbrook (HB) & Holbrook, PA & Rural & $\begin{array}{l}\text { Pennsylvania Department of } \\
\text { Environmental Protection (PA DEP) }\end{array}$ \\
\hline $\begin{array}{l}\text { Lawrenceville } \\
\text { (LW) }\end{array}$ & Pittsburgh, PA & Urban & $\begin{array}{l}\text { Allegheny County (PA) Health Department } \\
\text { (ACHD) }\end{array}$ \\
\hline $\begin{array}{l}\text { Morgantown } \\
\text { (MO) }\end{array}$ & Morgantown, WV & Urban & $\begin{array}{l}\text { West Virginia Department of } \\
\text { Environmental Protection (WV DEP) }\end{array}$ \\
\hline
\end{tabular}

Details regarding the location of these four sites as well as a summary of the ambient air parameters measured at each site are presented in Section 3 of this report. Sampling activities for the UORVP were initiated in February 1999 and concluded in February 2003.

\subsection{Project Goal and Objectives}

The goal of the UORVP was to characterize the nature and composition of $\mathrm{PM}_{2.5}$ and its precursor gases. In the process, the objectives of the UORVP were to address the following at sites located in the UORV:

- What are the ambient air concentrations of $\mathrm{PM}_{2.5}$ ?

- How do the ambient air concentrations of $\mathrm{PM}_{2.5}$ compare with the promulgated $\mathrm{PM}_{2.5}$ standards?

- Are there geographical, seasonal or temporal variations of ambient air concentrations of $\mathrm{PM}_{2.5}$ ?

- $\quad$ Are there significant differences in ambient air concentrations of $\mathrm{PM}_{2.5}$ at sites that deploy different types of $\mathrm{PM}_{2.5}$ samplers?

- What are the primary chemical constituents of $\mathrm{PM}_{2.5}$ ?

- Are there any correlations between ambient air concentrations of $\mathrm{PM}_{2.5}$ and its precursor gases?

- $\quad$ Are there any correlations between ambient air concentrations of $\mathrm{PM}_{2.5}$ and other gaseous pollutants (e.g., ozone)?

- Are there any correlations between ambient air concentrations of $\mathrm{PM}_{2.5}$ and meteorological parameters?

Advanced Technology Systems, Inc. (ATS) was contracted by the NETL in September 1998 to manage the UORVP. This semi-annual Technical Progress Report summarizes the data analyses 
and interpretations conducted during the period from October 2003 through March 2004. The organizational format for this report is as follows (per the Guidelines for Organization of Technical Reports [September 2003]):

1. Introduction

2. Executive Summary

3. Experimental

4. Results and Discussion

5. Conclusions

\subsection{Project Organization}

A list of the individuals with major responsibilities who participated in this project includes the following:

- $\quad$ NETL Program Manager for the UORVP

- $\quad \boldsymbol{A T S}$ Program Manager for the UORVP

- $\quad \boldsymbol{A T S}$ Coordinator for Sampling and Analytical Laboratory Activities

- $\quad$ Subcontract Analytical Laboratory Representatives

- $\quad$ Subcontract Site Operators

- $\quad$ Cooperating Regulatory Agency Representatives

An organization chart showing the relationships and the lines of communication among these individuals is presented in Figure 2. ATS contracted Desert Research Institute (DRI) to (i) provide many of the $\mathrm{PM}_{2.5}$ and precursor gas samplers not already deployed at the sites by the cooperating regulatory agency or $\boldsymbol{A T S}$ and (ii) conduct the required analyses of the samples generated by DRI's samplers. Details regarding DRI's organizational structure for the UORVP were previously presented in the document prepared by DRI entitled "Quality Integrated Work Plan (QIWP) for the Upper Ohio River Valley Project” dated April 27, 1999. 


\subsection{EXECUTIVE SUMMARY}

Advanced Technology Systems, Inc. (ATS), with Desert Research Institute (DRI) and Ohio University as subcontractors, was contracted by the NETL in September 1998 to manage the Upper Ohio River Valley Project (UORVP), which included the establishment and operation of four ambient air monitoring sites located in the Upper Ohio River Valley (UORV). Two urban and two rural monitoring sites were included in the UORVP. The four sites selected for the UOVRP were collocated at existing local and/or state air quality monitoring stations. The goal of the UORVP was to characterize the nature and composition of $\mathrm{PM}_{2.5}$ and its precursor gases. In the process, the objectives of the UORVP were to examine the ambient air concentrations of $\mathrm{PM}_{2.5}$ as compared with the promulgated $\mathrm{PM}_{2.5}$ standards, the geographical, seasonal and temporal variations of ambient air concentrations of $\mathrm{PM}_{2.5}$, the primary chemical constituents of $\mathrm{PM}_{2.5}$, and the correlations between ambient air concentrations of $\mathrm{PM}_{2.5}$ and its precursor gases, other gaseous pollutants and meteorological parameters. A variety of meteorological and pollutant measurement devices, including several different $\mathrm{PM}_{2.5}$ samplers that provided either real-time or integrated concentration data, were deployed at the monitoring sites. The frequency of integrated sampling varied throughout the UORVP study period and was as follows:

- "Intensive" sampling periods were defined as periods in which samples were collected on a relatively frequent basis (ranged from 6-hour integrated samples collected round-theclock to one 24-hour integrated sample collected every third day).

- $\quad$ "Background" sampling periods were defined as periods in which 24-hour integrated samples were collected every third or sixth day.

Sampling activities for the UORVP were initiated in February 1999 and concluded in February 2003. This semi-annual Technical Progress Report, which was organized in accordance with the Guidelines for Organization of Technical Reports (September 2003), summarizes the data analyses and interpretations conducted during the period from October 2003 through March 2004. The findings can be summarized as follows:

\section{Samples Collected During the Background Sampling Periods}

- $\quad$ The data collected during the background sampling periods suggests that $\mathrm{PM}_{2.5}$ mass concentrations are statistically the same at the LW, HB and MO sites.

- $\quad$ The data collected during the background sampling periods show that the overall average $\mathrm{PM}_{2.5}$ mass concentrations measured at the $\mathrm{HB}, \mathrm{LW}$ and $\mathrm{MO}$ sites are very nearly equal to the promulgated annual standard of $15 \mu \mathrm{g} / \mathrm{m}^{3}$ but far less than the 24-hour standard of $65 \mu \mathrm{g} / \mathrm{m}^{3}$.

- $\quad$ The data collected during the background sampling periods suggests that $L W \mathrm{PM}_{10}$ mass concentrations are statistically greater than the $\mathrm{HB} \mathrm{PM}_{10}$ mass concentrations. 
- $\quad$ The data collected during the background sampling periods show that the overall average $\mathrm{PM}_{10}$ mass concentrations measured at the $\mathrm{HB}$ and $\mathrm{LW}$ sites are far less than the promulgated annual standard of $50 \mu \mathrm{g} / \mathrm{m}^{3}$ and the 24-hour standard of $150 \mu \mathrm{g} / \mathrm{m}^{3}$.

\section{Samples Collected During the Intensive Sampling Periods}

- During the summer months, diurnal variations of $\mathrm{LW} \mathrm{PM}_{2.5}$ and $\mathrm{PM}_{10}$ mass concentrations were observed. The changes in concentrations from one 6-hour measurement period to the following 6-hour measurement period were not statistically significant except for $\mathrm{PM}_{10}$ (increase from 0000-0600 to 0600-1200, likely due to inputs from automotive sources during the morning hours).

- $\quad$ During the winter months, diurnal variations of $\mathrm{LW} \mathrm{PM}_{2.5}$ and $\mathrm{PM}_{10}$ mass concentrations were observed. The changes in concentrations from one 6-hour measurement period to the following 6-hour measurement period were not statistically significant except for (i) $\mathrm{PM}_{2.5}$ and $\mathrm{PM}_{10}$ (increase from 0000-0600 to 0600-1200, likely due to inputs from automotive sources during the morning hours and decreases in the atmospheric mixing height during nighttime hours) and (ii) $\mathrm{PM}_{2.5}$ and $\mathrm{PM}_{10}$ (decrease from 0600-1200 to 1200-1800, likely due to increases in the atmospheric mixing height during daytime hours).

- At the LW site, the data suggests that $\mathrm{PM}_{2.5}$ mass concentrations are usually higher during the summer season as compared with the winter season, although other factors (e.g., local sources and weather) apparently contribute in a manner sufficient to obfuscate the seasonal pattern. At the $\mathrm{HB}$ site, the data strongly suggests that $\mathrm{PM}_{2.5}$ mass concentrations are higher during the summer season as compared with the winter season, which is likely due to the occurrence of photochemical activity. There is insufficient quantity of data from the $\mathrm{MO}$ site to deduce any seasonal variations in $\mathrm{PM}_{2.5}$ mass concentrations at this site.

- At the LW site, the data suggests that there are no seasonal variations in $\mathrm{PM}_{10}$ mass concentrations at this site. At the $\mathrm{HB}$ site, the data suggests that $\mathrm{PM}_{10}$ mass concentrations may be higher during the summer season as compared with the winter season. However, the quantity of data from the HB site is not sufficient to strongly defend this conclusion.

\section{$\underline{\text { Implications }}$}

- $\quad$ The data obtained as part of the UORVP suggests that many regions within the UORV may be designated as non-attainment with respect to the annual $\mathrm{PM}_{2.5}$ standard. If this is realized, then the State Implementation Plans will likely mandate reducing air emissions of $\mathrm{PM}_{2.5}$ and/or its precursor gases from a large number of stationary, mobile and area sources that are located within a large geographical area. It should be noted that the UORV states (OH, PA and WV) submitted to the U.S. EPA in February 2004 a list of areas (counties) recommended to be designated to be in non-attainment with the $\mathrm{PM}_{2.5}$ standards. The U.S. EPA intends to rule upon the state recommendations later this year. 


\subsection{EXPERIMENTAL}

\subsection{Ambient Air Monitoring Site Locations}

Details regarding the locations of the four sites included in the UORVP are presented below:

\begin{tabular}{|c|c|c|c|}
\hline SITE & $\begin{array}{l}\text { LATITUDE AND } \\
\text { LONGITUDE }\end{array}$ & $\begin{array}{l}\text { ELEVATION } \\
\text { (ASL) }\end{array}$ & SITE DESCRIPTION \\
\hline AT & To be provided & $\begin{array}{l}\text { To be } \\
\text { provided }\end{array}$ & To be provided \\
\hline HB & $\begin{array}{l}\mathrm{N} 39^{\circ} \text { 48.969' } \\
\mathrm{W} 80^{\circ} 17.077^{\prime}\end{array}$ & $445 \mathrm{~m}$ & $\begin{array}{l}\text { Site located on privately-owned land near } \\
\text { Holbrook, PA; Terrain best described as } \\
\text { rolling grassy hills; Land usage includes cow } \\
\text { pasture; Sampling equipment located at } \\
\text { ground level within a fenced area situated on } \\
\text { a grassy knoll }\end{array}$ \\
\hline LW & $\begin{array}{l}\mathrm{N} 40^{\circ} 27.934^{\prime} \\
\mathrm{W}^{\prime} 9^{\circ} \text { 57.646 }\end{array}$ & $267 \mathrm{~m}$ & $\begin{array}{l}\text { Site located at the Allegheny County (PA) } \\
\text { Health Department complex; The complex is } \\
\text { situated within a joint residual and retail } \\
\text { business district of Pittsburgh, PA; Sampling } \\
\text { equipment located on the roof of Building } \\
\text { No. } 7 \text { ( } \sim 25 \text { feet above ground) }\end{array}$ \\
\hline $\mathrm{MO}$ & $\begin{array}{l}\mathrm{N} 39^{\circ} 39.003^{\prime} \\
\mathrm{W}^{\circ} 9^{\circ} 55.245^{\prime}\end{array}$ & $463 \mathrm{~m}$ & $\begin{array}{l}\text { Site located at the Morgantown, WV } \\
\text { Municipal Airport; Sampling equipment } \\
\text { located at ground level in a grassy field } \\
\text { within the complex }\end{array}$ \\
\hline
\end{tabular}

The LW site is the most northern and second most eastern of the four UORVP sites while the AT site is the most southern and western of the four UORVP sites. Since the prevailing wind direction in the Pittsburgh, PA area is westerly, it is expected that the LW site would generally be impacted the most by air emissions sources located in the UORV and the AT site would generally be impacted the least by air emissions sources located in the UORV. Digital images of the four sites are presented in Appendix A. 


\subsection{Ambient Air Parameters and Sampling / Analytical Methodologies}

The following ambient air parameters were quantified at one or more of the following UORVP sites:

- $\quad$ Mass concentrations of $\mathrm{PM}_{2.5}$ and $\mathrm{PM}_{10}$

- Chemical composition of $\mathrm{PM}_{2.5}$ and $\mathrm{PM}_{10}$ - includes organic and elemental carbon, water soluble ions and selected elements (primarily metals)

- $\quad$ Particle size analysis of $\mathrm{PM}_{2.5}$

- $\quad$ Concentrations of photo-chemically produced reactive gases - nitric acid $\left(\mathrm{HNO}_{3}\right)$

- $\quad$ Concentrations of naturally occurring reactive gases - ammonia $\left(\mathrm{NH}_{3}\right)$

- $\quad$ Concentrations of gaseous criteria pollutants - ozone $\left(\mathrm{O}_{3}\right)$, nitrogen oxides $\left(\mathrm{NO}_{\mathrm{x}}\right)$, sulfur dioxide $\left(\mathrm{SO}_{2}\right)$ and carbon monoxide $(\mathrm{CO})$

- $\quad$ Meteorological parameters - wind speed and direction, temperature, relative humidity, solar radiation and precipitation depth

A summary of the ambient air parameters and the associated measurement techniques deployed at each of the four UORVP sites is presented in Table 1. Several different measurement techniques were utilized to measure integrated (over time) $\mathrm{PM}_{2.5}$ and $\mathrm{PM}_{10}$ ambient air concentrations. The instrumentation for the integrated measurement technique essentially includes an inlet particle size separator (impactor or cyclone), an optional denuder for removing selected gases (e.g., $\mathrm{HNO}_{3}$ ), a filter pack loaded with multiple filters, a vacuum pump and a device for measuring sample gas volume. For the purposes of the UORVP, all integrated $\mathrm{PM}_{2.5}$ samplers were assumed to be equivalent. One measurement technique (TEOM) was utilized to measure real-time (continuous) $\mathrm{PM}_{2.5}$ and $\mathrm{PM}_{10}$ ambient air concentrations. The instrumentation for the real-time measurement technique essentially includes an inlet particle size separator (impactor or cyclone), an oscillating microbalance, a vacuum pump and a device for measuring sample gas volume. Details regarding the DRI samplers and their analytical laboratory procedures were previously presented in the DRI QIWP. All other samplers and measurement devices were operated in accordance with the manufacturer's instructions and each operating group's quality assurance project plan.

\subsection{Sampling Schedule}

The analyzers that provided real-time data were designed to operate on a continuous basis throughout the UORVP study period. The sampling and analysis logs for the analyzers that provided integrated data are presented in Tables 2 through 6 . The frequency of integrated sampling varied throughout the UORVP study period and was as follows:

- "Intensive" sampling periods were defined as periods in which samples were collected on a relatively frequent basis (ranged from 6-hour integrated samples collected round-theclock to one 24-hour integrated sample collected every third day). 
- "Background" sampling periods were defined as periods in which 24-hour integrated samples were collected every third or sixth day.

For each sampling period, all appropriate samples were analyzed for $\mathrm{PM}_{2.5}$ or $\mathrm{PM}_{10}$ mass concentration. For each sampling period, a subset of selected samples was analyzed for targeted elements, ions or compounds. As outlined in Tables 2 though 6, there were very few samples collected during the background sampling periods that were analyzed for targeted elements, ions or compounds. As such, discussions regarding the chemical composition of the collected samples (Section 4 of this report) will be limited to samples collected during the intensive sampling periods. 


\subsection{RESULTS AND DISCUSSION}

\subsection{Current Data Status for the UORVP Sites}

Summaries of the current data statuses for the AT, HB, LW and MO sites are presented in Tables 7 through 10, respectively. All available data have been obtained by ATS except for the data collected by the OH EPA and WV DEP at the AT and MO sites, respectively - ATS intends to request these data soon. Groups external to ATS provided validated data - the validation procedures can be obtained by ATS upon request. No data collected by ATS alone (the TEOM data for $\mathrm{HB}$ and $\mathrm{LW}$, the $\mathrm{NO}_{\mathrm{x}}$ data for $\mathrm{HB}$, and the $\mathrm{SO}_{2}$ and meteorological data for $\mathrm{LW}$ ) have been validated to date. ATS submits that all validated data will require additional "filtering" in order to develop a final data set that will be utilized for the data analyses and interpretation. Such filtering step will include the following:

\section{For Data Obtained Using Continuous Analyzers}

- $\quad$ Eliminate voided and missing data (these values are often assigned the value of -99)

- Reassign values that are less than the accepted detection limit / threshold value of the continuous analyzer

- $\quad$ Eliminate other suspicious data as judged by ATS

For Data Obtained Using Integrated Samplers

- $\quad$ Eliminate voided and missing data (these values are often assigned the value of -99)

- $\quad$ Eliminate duplicate data entries that present different values (i.e., two data entries with the same identification but differing analytical values)

- "Blank correct" the results for minor contamination if not already performed by the group that submitted the data to ATS (DRI submitted blank-corrected data while Chester LabNet did not) - ATS intends to eliminate data for which the contamination was not considered minor

- $\quad$ For the data provided by DRI, eliminate samples (paired observations only) at the HB and LW sites that satisfied the following criteria:

$\mathrm{PM}_{10}$ mass concentration $<\mathrm{PM}_{2.5}$ mass concentration; and

The associated error bars did not overlap

- $\quad$ For the data provided by DRI, eliminate samples that satisfied the following criteria:

$\mathrm{PM}_{2.5}$ or $\mathrm{PM}_{10}$ mass concentrations $<$ Sum of the individual chemical concentrations for $\mathrm{PM}_{2.5}$ or $\mathrm{PM}_{10}$; and

The associated concentration error bars did not overlap

- $\quad$ For the data provided by DRI, eliminate samples that satisfied the following criteria:

Total chlorine concentration < Water-soluble chloride concentration; and

The associated concentration error bars did not overlap 
- $\quad$ For the data provided by DRI, eliminate samples that satisfied the following criteria:

Total potassium concentration $<$ Water-soluble potassium concentration; and

The associated concentration error bars did not overlap

- $\quad$ For the data provided by DRI, eliminate samples that satisfied the following criteria:

Charge Balance Ratio $<0.80$ or Charge Balance Ratio $>1.20$

where Charge Balance Ratio (equivalents basis) =

Sum of the water-soluble cations / Sum of the water-soluble anions

- $\quad$ Eliminate other suspicious data as judged by ATS

It should be noted that DRI provided an extensive data summary. Per DRI's standard operating procedures (SOPs), data entries were flagged (using a variety of descriptors) as appropriate if (i) nonstandard procedures were utilized in the field or in the laboratory or (ii) peculiar observations of the samples were noted. DRI voided some samples as appropriate (occurred primarily due to field equipment failures) and elected to report the remainder of the data either with or without data flags. DRI's SOPs reserve the right for the end user of the data to accept or reject flagged data entries. ATS adopted a fairly conservative approach for filtering DRI's data prior to conducting the analyses presented in this report (i.e., ATS excluded many, but not all, of the flagged data entries - depended on the nature of the flag).

The data analyses presented in the following sections summarizes the efforts from the integrated filter sampling at the HB, LW and MO sites. These analyses were previously presented in the most recent semi-annual technical report.

\subsection{Data Collected During the Background Sampling Periods \\ 4.2.1 $\mathrm{PM}_{2.5}$ Mass Concentrations - Site Comparisons - DRI Sampling Equipment}

For the LW, $\mathrm{HB}$ and $\mathrm{MO}$ sites, examine the 24-hour integrated $\mathrm{PM}_{2.5}$ mass concentrations (samples were collected every sixth day) - composite data were generated that sorted the concentrations by the common sample date (not examining seasonal variations in $\mathrm{PM}_{2.5}$ mass concentrations here) -

(i) Calculate the Spearman Rank Correlation Coefficient $\left(r_{s}\right)$ for each pairing (LW/HB, $\mathrm{LW} / \mathrm{MO}$ and $\mathrm{HB} / \mathrm{MO}$ ) - the results are as follows:

\begin{tabular}{|c|c|c|}
\hline $\begin{array}{c}\text { Pairing } \\
\left(\mathbf{P M}_{\mathbf{2 . 5}} \mathbf{D R I}\right)\end{array}$ & $\begin{array}{c}\mathbf{r}_{\mathbf{s}} \\
\text { value }\end{array}$ & Conclusion \\
\hline $\mathrm{LW} / \mathrm{HB}$ & 0.70 & Reasonably good positive correlation between LW and HB \\
\hline $\mathrm{LW} / \mathrm{MO}$ & 0.71 & Reasonably good positive correlation between LW and MO \\
\hline
\end{tabular}

U.S. DOE NETL 40456R09

ATS Project No. 98-839-P 


\begin{tabular}{|c|c|c|}
\hline $\begin{array}{c}\text { Pairing } \\
\text { (PM } \text { (P..5 DRI) }^{2}\end{array}$ & $\begin{array}{c}r_{s} \\
\text { value }\end{array}$ & Conclusion \\
\hline $\mathrm{HB} / \mathrm{MO}$ & 0.65 & Reasonably good positive correlation between $\mathrm{HB}$ and $\mathrm{MO}$ \\
\hline
\end{tabular}

A scatter plot for each pairing also confirms the positive correlations.

(ii) Calculate the differences for each pairing (LW/HB, LW/MO and HB/MO) - Run a statistical hypothesis test to determine if the average difference for each pairing is significantly different from zero at the 95 percent confidence level - the results are as follows:

\begin{tabular}{|l|l|}
\hline \multicolumn{1}{|c|}{$\begin{array}{c}\text { Pairing } \\
\left(\mathbf{P M}_{\mathbf{2 . 5}} \text { DRI) }\right.\end{array}$} & \multicolumn{1}{c|}{ Conclusion } \\
\hline $\mathrm{LW} / \mathrm{HB}$ & $\begin{array}{l}\text { Insufficient data to conclude that the average difference is } \\
\text { significantly different from zero }\end{array}$ \\
\hline $\mathrm{LW} / \mathrm{MO}$ & Ibid. \\
\hline $\mathrm{HB} / \mathrm{MO}$ & Ibid. \\
\hline
\end{tabular}

Essentially, the data collected during the background sampling periods suggests that $\mathrm{PM}_{2.5}$ mass concentrations are statistically the same at the LW, $\mathrm{HB}$ and $\mathrm{MO}$ sites.

(iii) Compare the $\mathrm{PM}_{2.5}$ mass concentrations measured at the LW, $\mathrm{HB}$ and $\mathrm{MO}$ sites with the promulgated $\mathrm{PM}_{2.5}$ mass concentration standards -

24-hour standard $=65 \mu \mathrm{g} / \mathrm{m}^{3}$ measured as the $98^{\text {th }}$ percentile of the 24 -hour $\mathrm{PM}_{2.5}$ mass concentrations in a year (averaged over three years)

Annual standard $=15 \mu \mathrm{g} / \mathrm{m}^{3}$ measured as the three year average of the annual arithmetic mean

The results are as follows:

\begin{tabular}{|l|l|l|l|}
\hline Site & $\begin{array}{c}\text { Overall Average } \\
\text { PM }_{\mathbf{2 . 5}} \text { Conc. (DRI) }\end{array}$ & $\begin{array}{c}\mathbf{5 0}^{\text {th }} \text { Percentile } \text { PM }_{2.5} \\
\text { Conc. (DRI) }\end{array}$ & $\begin{array}{c}\mathbf{9 8}^{\text {th }} \text { Percentile } \text { PM }_{\mathbf{2 . 5}} \\
\text { Conc. (DRI) }\end{array}$ \\
\hline $\mathrm{LW}$ & $14.4 \mu \mathrm{g} / \mathrm{m}^{3}$ & $12.5 \mu \mathrm{g} / \mathrm{m}^{3}$ & $32.7 \mu \mathrm{g} / \mathrm{m}^{3}$ \\
\hline $\mathrm{HB}$ & $13.0 \mu \mathrm{g} / \mathrm{m}^{3}$ & $10.4 \mu \mathrm{g} / \mathrm{m}^{3}$ & $35.0 \mu \mathrm{g} / \mathrm{m}^{3}$ \\
\hline
\end{tabular}




\begin{tabular}{|c|c|c|c|}
\hline Site & $\begin{array}{c}\text { Overall Average } \\
\mathbf{P M}_{\mathbf{2 . 5}} \text { Conc. (DRI) }\end{array}$ & $\begin{array}{c}\mathbf{5 0}^{\text {th }} \text { Percentile } \text { PM }_{\mathbf{2 . 5}} \\
\text { Conc. (DRI) }\end{array}$ & $\begin{array}{c}\mathbf{9 8}^{\text {th }} \text { Percentile } \text { PM }_{\mathbf{2 . 5}} \\
\text { Conc. (DRI) }\end{array}$ \\
\hline $\mathrm{MO}$ & $16.3 \mu \mathrm{g} / \mathrm{m}^{3}$ & $15.6 \mu \mathrm{g} / \mathrm{m}^{3}$ & $34.6 \mu \mathrm{g} / \mathrm{m}^{3}$ \\
\hline
\end{tabular}

The results show that the overall average $\mathrm{PM}_{2.5}$ mass concentrations measured at the $\mathrm{HB}$, LW and MO sites are very nearly equal to the promulgated annual standard of $15 \mu \mathrm{g} / \mathrm{m}^{3}$ but far less than the 24-hour standard of $65 \mu \mathrm{g} / \mathrm{m}^{3}$.

\subsection{2 $\mathrm{PM}_{10}$ Mass Concentrations - Site Comparisons - DRI Sampling Equipment}

For the LW and HB sites, examine the 24-hour integrated $\mathrm{PM}_{10}$ mass concentrations (samples were collected every sixth day) - composite data were generated that sorted the concentrations by the common sample date (not examining seasonal variations in $\mathrm{PM}_{10}$ mass concentrations here) -

(i) Calculate the Spearman Rank Correlation Coefficient $\left(\mathrm{r}_{\mathrm{s}}\right)$ for the LW/HB pairing - the results are as follows:

\begin{tabular}{|l|c|c|}
\hline Pairing (PM (PR $_{\text {10 }}$ DR) & $\begin{array}{c}\mathbf{r}_{\mathbf{s}} \\
\text { value }\end{array}$ & Conclusion \\
\hline $\mathrm{LW} / \mathrm{HB}$ & 0.80 & Good positive correlation between LW and HB \\
\hline
\end{tabular}

A scatter plot for the pairing also confirms the positive correlations.

(ii) Calculate the differences for the LW/HB pairing - Run a statistical hypothesis test to determine if the average difference for the pairing is significantly different from zero at the 95 percent confidence level - the results are as follows:

\begin{tabular}{|l|l|}
\hline Pairing (PM10 $\mathbf{~ D R I ) ~}$ & Conclusion \\
\hline $\mathrm{LW} / \mathrm{HB}$ & $\begin{array}{l}\text { The average difference is significantly different from zero } \\
(\mathrm{LW}>\mathrm{HB})\end{array}$ \\
\hline
\end{tabular}

The data collected during the background sampling periods suggests that there is a larger number of $\mathrm{PM}_{10}$ sources that impact the LW site as compared with the HB site.

(iii) Compare the $\mathrm{PM}_{10}$ mass concentrations measured at the LW and $\mathrm{HB}$ sites with the promulgated $\mathrm{PM}_{10}$ mass concentration standards - 
$\underline{\text { 24-hour standard }}=150 \mu \mathrm{g} / \mathrm{m}^{3}$ measured as the $99^{\text {th }}$ percentile of the 24 -hour $\mathrm{PM}_{2.5}$ mass concentrations in a year (averaged over three years)

$\underline{\text { Annual standard }}=50 \mu \mathrm{g} / \mathrm{m}^{3}$ measured as an annual arithmetic mean

The results are as follows:

\begin{tabular}{|l|l|l|l|}
\hline Site & $\begin{array}{c}\text { Overall Average } \\
\text { PM }_{\mathbf{1 0}} \text { Conc. (DRI) }\end{array}$ & $\begin{array}{c}\mathbf{5 0}^{\text {th }} \text { Percentile PM } \\
\text { Conc. (DRI) }\end{array}$ & $\begin{array}{c}\mathbf{9 9}^{\text {th }} \text { Percentile PM } \\
\text { Conc. (DRI) }\end{array}$ \\
\hline $\mathrm{LW}$ & $22.3 \mu \mathrm{g} / \mathrm{m}^{3}$ & $20.4 \mu \mathrm{g} / \mathrm{m}^{3}$ & $52.6 \mu \mathrm{g} / \mathrm{m}^{3}$ \\
\hline $\mathrm{HB}$ & $17.0 \mu \mathrm{g} / \mathrm{m}^{3}$ & $14.2 \mu \mathrm{g} / \mathrm{m}^{3}$ & $49.0 \mu \mathrm{g} / \mathrm{m}^{3}$ \\
\hline
\end{tabular}

The results show that the overall average $\mathrm{PM}_{10}$ mass concentrations measured at the $\mathrm{HB}$ and LW sites are far less than the promulgated annual standard of $50 \mu \mathrm{g} / \mathrm{m}^{3}$ and the 24hour standard of $150 \mu \mathrm{g} / \mathrm{m}^{3}$.

\subsubsection{Comparison of $\mathrm{PM}_{2.5}$ with $\mathrm{PM}_{10}$ Mass Concentrations - DRI Sampling Equipment}

For the LW and HB sites, examine the 24-hour integrated $\mathrm{PM}_{2.5}$ and $\mathrm{PM}_{10}$ mass concentrations (samples were collected every sixth day) - composite data were generated that sorted the concentrations by the common sample date (not examining seasonal variations in $\mathrm{PM}_{2.5}$ and $\mathrm{PM}_{10}$ mass concentrations here) -

(i) For the LW and HB sites, calculate the Spearman Rank Correlation Coefficient ( $\mathrm{r}_{\mathrm{s}}$ ) for each $\mathrm{PM}_{2.5} / \mathrm{PM}_{10}$ pairing - the results are as follows:

\begin{tabular}{|c|c|l|}
\hline Pairing (DRI) & $\begin{array}{c}\mathbf{r}_{\mathbf{s}} \\
\text { value }\end{array}$ & \multicolumn{1}{c|}{ Conclusion } \\
\hline $\mathrm{LW} \mathrm{PM}_{2.5} / \mathrm{PM}_{10}$ & 0.85 & Very good positive correlation at the LW site \\
\hline $\mathrm{HB} \mathrm{PM}_{2.5} / \mathrm{PM}_{10}$ & 0.84 & Very good positive correlation at the HB site \\
\hline
\end{tabular}

A scatter plot for each pairing also confirms the positive correlation.

(ii) For the LW and HB sites, calculate the differences for each $\mathrm{PM}_{2.5} / \mathrm{PM}_{10}$ pairing - Run a statistical hypothesis test to determine if the average difference for each pairing is significantly different from zero at the 95 percent confidence level - the results are as follows: 


\begin{tabular}{|c|l|}
\hline Pairing (DRI) & \multicolumn{1}{c|}{ Conclusion } \\
\hline $\mathrm{LW} \mathrm{PM}_{2.5} / \mathrm{PM}_{10}$ & $\begin{array}{l}\text { The average difference is significantly different from zero at the } \\
\mathrm{LW} \text { site }\left(\mathrm{PM}_{10}>\mathrm{PM}_{2.5}\right)\end{array}$ \\
\hline $\mathrm{HB} \mathrm{PM}_{2.5} / \mathrm{PM}_{10}$ & $\begin{array}{l}\text { The average difference is significantly different from zero at the } \\
\mathrm{HB} \text { site }\left(\mathrm{PM}_{10}>\mathrm{PM}_{2.5}\right)\end{array}$ \\
\hline
\end{tabular}

If the sampling equipment is operating properly, then these are the expected results.

\subsubsection{Comparison of $\mathrm{PM}_{2.5}$ Mass Concentrations - DRI Sampling Equipment with $\mathrm{PM}_{2.5}$ Mass Concentrations - FRM Sampling Equipment}

For the LW and HB sites, examine the 24-hour integrated $\mathrm{PM}_{2.5}$ mass concentrations (samples were collected every sixth day) that were measured using the DRI and the FRM sampling equipment - composite data were generated that sorted the concentrations by the common sample date (not examining seasonal variations in $\mathrm{PM}_{2.5}$ mass concentrations here) -

(i) For the LW and HB sites, calculate the Spearman Rank Correlation Coefficient $\left(r_{s}\right)$ for each DRI / FRM pairing - the results are as follows:

\begin{tabular}{|c|c|c|}
\hline Pairing $\left(\mathrm{PM}_{2.5}\right)$ & $\begin{array}{c}\mathbf{r}_{\mathbf{s}} \\
\text { value }\end{array}$ & Conclusion \\
\hline LW DRI / FRM & 0.92 & Very good positive correlation at the LW site \\
\hline HB DRI / FRM & 0.90 & Very good positive correlation at the HB site \\
\hline
\end{tabular}

A scatter plot for each pairing also confirms the positive correlation.

(ii) For the LW and HB sites, calculate the differences for each DRI / FRM pairing - Run a statistical hypothesis test to determine if the average difference for each pairing is significantly different from zero at the 95 percent confidence level - the results are as follows:

\begin{tabular}{|l|l|}
\hline \multicolumn{1}{|c|}{ Pairing $\left(\mathbf{P M}_{\mathbf{2 . 5}}\right)$} & \multicolumn{1}{c|}{ Conclusion } \\
\hline LW DRI / FRM & $\begin{array}{l}\text { Insufficient data to conclude that the average difference is } \\
\text { significantly different from zero }\end{array}$ \\
\hline HB DRI / FRM & $\begin{array}{l}\text { The average difference is significantly different from zero at } \\
\text { the HB site (DRI > FRM) }\end{array}$ \\
\hline
\end{tabular}


The results summarized above present different conclusions for identical tests performed at two separate sites. To further understand these conclusions, an additional statistical hypothesis test was run in a manner similar to the test described in Section 1.1(ii). Calculate the differences for the LW/HB FRM pairings - Run a statistical hypothesis test to determine if the average difference for the pairing is significantly different from zero at the 95 percent confidence level - the results are as follows:

\begin{tabular}{|l|l|}
\hline Pairing (PM $\mathbf{2 . 5})$ & \multicolumn{1}{c|}{ Conclusion } \\
\hline FRM LW / HB & $\begin{array}{l}\text { The average difference is significantly different from zero (LW > } \\
\text { HB) }\end{array}$ \\
\hline
\end{tabular}

The result summarized above does not match the result summarized in Section 1.1 using the DRI sampling equipment $\left(\mathrm{PM}_{2.5}\right.$ DRI LW / HB). As such, we conclude that the $\mathrm{PM}_{2.5}$ data generated with the FRM sampling equipment at the HB site may be suspect.

\subsection{Data Collected During the Intensive Sampling Periods}

\subsubsection{Diurnal Variations of $L W \mathrm{PM}_{2.5}$ and $\mathrm{PM}_{10}$ Mass Concentrations - DRI Sampling Equipment}

For the LW site, examine the 6-hour integrated $\mathrm{PM}_{2.5}$ and $\mathrm{PM}_{10}$ mass concentrations to determine the presence of diurnal variations of these concentrations - For $\mathrm{PM}_{2.5}$ and $\mathrm{PM}_{10}$, calculate the difference in the concentrations for each consecutive 6-hour sampling period (i.e., concentration for [0600 to 1200] time period minus the concentration for the [0000 to 0600] time period) - composite data were generated that sorted the differences by the common sampling comparison period and the season of the year (summer or winter) - Run a statistical hypothesis test to determine if the average difference for each seasonal sampling comparison period is significantly different from zero at the 95 percent confidence level - the results are as follows:

\section{Legend}

$\uparrow \quad$ Average difference in concentration for consecutive 6-hour sampling periods $>0$

$\downarrow \quad$ Average difference in concentration for consecutive 6-hour sampling periods $<0$ (size of $\uparrow$ and $\downarrow$ approximates the value of the average difference)

$\sqrt{ } \quad$ Average difference is significantly different from zero

LW PM 2.5 - Summer

\begin{tabular}{|lllll|}
\hline $1800-2400$ & $\downarrow$ & & $\uparrow$ & $\downarrow$ \\
$0000-0600$ & & & & \\
$0600-1200$ & $1200-1800$ & $1800-2400$ \\
\hline
\end{tabular}




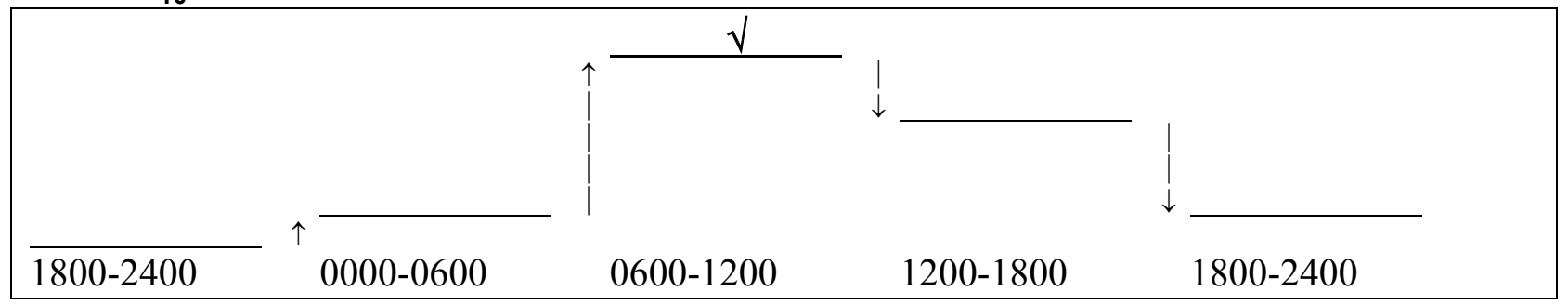

\section{LW PM $2.5-$ Winter}

\begin{tabular}{|c|c|c|c|c|}
\hline & & $\sqrt{ }$ & & \\
\hline & $\downarrow$ & & 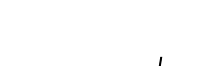 & \\
\hline $1800-2400$ & $0000-0600$ & $0600-1200$ & $\frac{v}{1200-1800}$ & $1800-2400$ \\
\hline
\end{tabular}

\section{LW PM $M_{10}-$ Winter}

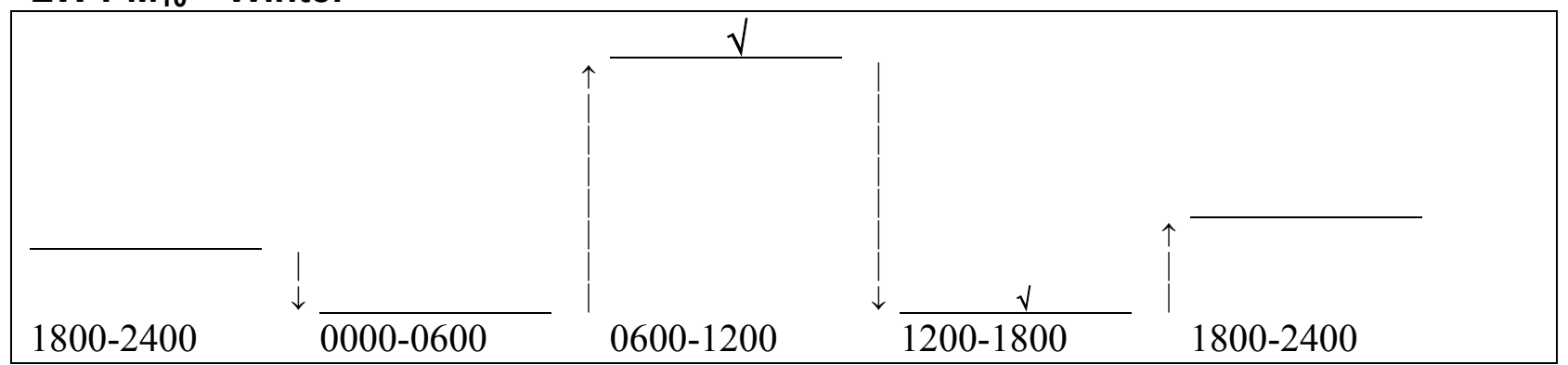

During the winter season, the changes in $\mathrm{PM}_{2.5}$ and $\mathrm{PM}_{10}$ mass concentrations are likely due to (i) inputs from automotive sources during the morning hours and (ii) increases and decreases in the atmospheric mixing height during daytime and nighttime hours, respectively. During the summer season, the changes in $\mathrm{PM}_{2.5}$ and $\mathrm{PM}_{10}$ mass concentrations are likely due to the factors outlined above and to the occurrence of atmospheric photochemical activity (especially for $\mathrm{PM}_{2.5}$ ).

\subsubsection{Seasonal Variations of $\mathrm{PM}_{2.5}$ Mass Concentrations - Site Comparisons - DRI Sampling Equipment}

Compare the $\mathrm{PM}_{2.5}$ mass concentrations measured at the LW, HB and MO sites with the promulgated $\mathrm{PM}_{2.5}$ mass concentration standards for each sampling period - the results are as follows: 
24-hour standard $=65 \mu \mathrm{g} / \mathrm{m}^{3}$ measured as the $98^{\text {th }}$ percentile of the 24-hour $\mathrm{PM}_{2.5}$ mass concentrations in a year (averaged over three years)

LW PM 2.5 (DRI)

\begin{tabular}{|l|l|l|l|}
\hline \multicolumn{1}{|c|}{ Season } & \multicolumn{1}{|c|}{ Sampling Dates } & \multicolumn{1}{c|}{$\begin{array}{c}\mathbf{5 0}^{\text {th }} \text { Percentile } \\
\mathbf{P M}_{\mathbf{2 . 5}} \text { Conc. (DRI) }\end{array}$} & $\begin{array}{c}\mathbf{9 8}^{\text {th }} \text { Percentile } \\
\mathbf{P M}_{\mathbf{2 . 5}} \text { Conc. (DRI) }\end{array}$ \\
\hline Winter & $02 / 17 / 1999-02 / 28 / 1999 *$ & $12.6 \mu \mathrm{g} / \mathrm{m}^{3}$ & $34.2 \mu \mathrm{g} / \mathrm{m}^{3}$ \\
\hline Summer & $08 / 03 / 1999-09 / 11 / 1999 *$ & $15.2 \mu \mathrm{g} / \mathrm{m}^{3}$ & $36.0 \mu \mathrm{g} / \mathrm{m}^{3}$ \\
\hline Winter & $01 / 12 / 2000-02 / 18 / 2000 *$ & $13.7 \mu \mathrm{g} / \mathrm{m}^{3}$ & $32.5 \mu \mathrm{g} / \mathrm{m}^{3}$ \\
\hline Summer & $07 / 17 / 2000-08 / 25 / 2000 *$ & $15.0 \mu \mathrm{g} / \mathrm{m}^{3}$ & $38.8 \mu \mathrm{g} / \mathrm{m}^{3}$ \\
\hline Summer & $06 / 30 / 2001-08 / 08 / 2001 *$ & $18.8 \mu \mathrm{g} / \mathrm{m}^{3}$ & $52.8 \mu \mathrm{g} / \mathrm{m}^{3}$ \\
\hline Winter & $01 / 02 / 2002-01 / 22 / 2002$ & $15.8 \mu \mathrm{g} / \mathrm{m}^{3}$ & $20.5 \mu \mathrm{g} / \mathrm{m}^{3}$ \\
\hline Fall \& Winter & $10 / 01 / 2002-02 / 27 / 2003$ & $9.9 \mu \mathrm{g} / \mathrm{m}^{3}$ & $27.1 \mu \mathrm{g} / \mathrm{m}^{3}$ \\
\hline
\end{tabular}

*: 6-hour integrated samples rather than 24-hour integrated samples

$\mathrm{HB} \mathrm{PM}_{2.5}$ (DRI)

\begin{tabular}{|l|l|l|l|}
\hline Season & Sampling Dates & $\begin{array}{l}\mathbf{5 0}^{\text {th }} \text { Percentile } \\
\mathbf{P M}_{\mathbf{2 . 5}} \text { Conc. (DRI) }\end{array}$ & $\begin{array}{l}\mathbf{9 8}^{\text {th }} \text { Percentile } \\
\mathbf{P M}_{\mathbf{2}} \text { Conc. (DRI) }\end{array}$ \\
\hline Winter & $02 / 17 / 1999-02 / 28 / 1999$ & $\begin{array}{l}\text { N/A less than } 20 \\
\text { samples available }\end{array}$ & $\begin{array}{l}\text { N/A - less than } 20 \\
\text { samples available }\end{array}$ \\
\hline Summer & $08 / 03 / 1999-09 / 11 / 1999$ & $15.8 \mu \mathrm{g} / \mathrm{m}^{3}$ & $29.6 \mu \mathrm{g} / \mathrm{m}^{3}$ \\
\hline Winter & $01 / 12 / 2000-02 / 17 / 2000$ & $8.4 \mu \mathrm{g} / \mathrm{m}^{3}$ & $16.0 \mu \mathrm{g} / \mathrm{m}^{3}$ \\
\hline Summer & $07 / 17 / 2000-08 / 25 / 2000$ & $18.0 \mu \mathrm{g} / \mathrm{m}^{3}$ & $36.9 \mu \mathrm{g} / \mathrm{m}^{3}$ \\
\hline Summer & $07 / 02 / 2001-08 / 08 / 2001$ & $27.5 \mu \mathrm{g} / \mathrm{m}^{3}$ & $55.9 \mu \mathrm{g} / \mathrm{m}^{3}$ \\
\hline Winter & $01 / 02 / 2002-01 / 22 / 2002$ & $9.7 \mu \mathrm{g} / \mathrm{m}^{3}$ & $15.4 \mu \mathrm{g} / \mathrm{m}^{3}$ \\
\hline
\end{tabular}


MO PM ${ }_{2.5}(\mathrm{DRI})$

\begin{tabular}{|l|l|l|l|}
\hline Season & \multicolumn{1}{|c|}{ Sampling Dates } & \multicolumn{1}{|c|}{$\begin{array}{c}\mathbf{5 0}^{\text {th }} \text { Percentile } \\
\mathbf{P M}_{\mathbf{2 . 5}} \text { Conc. (DRI) }\end{array}$} & $\begin{array}{c}\mathbf{9 8}^{\text {th }} \text { Percentile } \\
\mathbf{P M}_{\mathbf{2 . 5}} \text { Conc. (DRI) }\end{array}$ \\
\hline Winter & $01 / 13 / 2000-02 / 18 / 2000$ & $\begin{array}{l}\text { N/A - less than } 20 \\
\text { samples available }\end{array}$ & $\begin{array}{l}\text { N/A - less than } 20 \\
\text { samples available }\end{array}$ \\
\hline Summer & $08 / 21 / 1999-08 / 05 / 2001$ & $\begin{array}{l}20.3 \mu \mathrm{g} / \mathrm{m}^{3}(29 \\
\text { samples available) }\end{array}$ & $\begin{array}{l}38.3 \mu \mathrm{g} / \mathrm{m}^{3}(29 \\
\text { samples available) }\end{array}$ \\
\hline
\end{tabular}

At the LW site, the data suggests that $\mathrm{PM}_{2.5}$ mass concentrations are usually higher during the summer season as compared with the winter season, although other factors (e.g., local sources and weather) apparently contribute in a manner sufficient to obfuscate the seasonal pattern. At the $\mathrm{HB}$ site, the data strongly suggests that $\mathrm{PM}_{2.5}$ mass concentrations are higher during the summer season as compared with the winter season, which is likely due to the occurrence of photochemical activity. There is insufficient quantity of data from the MO site to deduce any seasonal variations in $\mathrm{PM}_{2.5}$ mass concentrations at this site.

\subsubsection{Seasonal Variations of $\mathrm{PM}_{10}$ Mass Concentrations - Site Comparisons - DRI Sampling Equipment}

Compare the $\mathrm{PM}_{10}$ mass concentrations measured at the LW and HB sites with the promulgated $\mathrm{PM}_{10}$ mass concentration standards for each sampling period - the results are as follows:

24-hour standard $=150 \mu \mathrm{g} / \mathrm{m}^{3}$ measured as the $99^{\text {th }}$ percentile of the 24-hour $\mathrm{PM}_{10}$ mass concentrations in a year (averaged over three years)

\section{LW PM 10 (DRI)}

\begin{tabular}{|l|l|l|l|}
\hline Season & Sampling Dates & $\begin{array}{l}\mathbf{5 0}^{\text {th }} \text { Percentile } \text { PM }_{\mathbf{2 . 5}} \\
\text { Conc. (DRI) }\end{array}$ & $\begin{array}{l}\mathbf{9 9}^{\text {th }} \text { Percentile } \text { PM }_{\mathbf{2 . 5}} \\
\text { Conc. (DRI) }\end{array}$ \\
\hline Winter & $02 / 17 / 1999-02 / 28 / 1999 *$ & $16.6 \mu \mathrm{g} / \mathrm{m}^{3}$ & $48.9 \mu \mathrm{g} / \mathrm{m}^{3}$ \\
\hline Summer & $08 / 03 / 1999-09 / 11 / 1999 *$ & $22.9 \mu \mathrm{g} / \mathrm{m}^{3}$ & $53.7 \mu \mathrm{g} / \mathrm{m}^{3}$ \\
\hline Winter & $01 / 12 / 2000-02 / 18 / 2000 *$ & $19.4 \mu \mathrm{g} / \mathrm{m}^{3}$ & $56.5 \mu \mathrm{g} / \mathrm{m}^{3}$ \\
\hline Summer & $07 / 17 / 2000-08 / 25 / 2000 *$ & $20.5 \mu \mathrm{g} / \mathrm{m}^{3}$ & $48.8 \mu \mathrm{g} / \mathrm{m}^{3}$ \\
\hline Summer & $07 / 02 / 2001-08 / 07 / 2001 *$ & $25.8 \mu \mathrm{g} / \mathrm{m}^{3}$ & $70.3 \mu \mathrm{g} / \mathrm{m}^{3}$ \\
\hline
\end{tabular}

*: 6-hour integrated samples rather than 24-hour integrated samples 
HB PM 10 (DRI)

\begin{tabular}{|l|l|l|l|}
\hline Season & Sampling Dates & $\begin{array}{l}\mathbf{5 0}^{\text {th }} \text { Percentile } \text { PM }_{\mathbf{2 . 5}} \\
\text { Conc. (DRI) }\end{array}$ & $\begin{array}{l}\mathbf{9 9}^{\text {th }} \text { Percentile } \text { PM }_{\mathbf{2 . 5}} \\
\text { Conc. (DRI) }\end{array}$ \\
\hline Winter & $02 / 17 / 1999-02 / 28 / 1999$ & $\begin{array}{l}\text { N/A - less than 20 } \\
\text { samples available }\end{array}$ & $\begin{array}{l}\text { N/A - less than 20 } \\
\text { samples available }\end{array}$ \\
\hline Summer & $08 / 03 / 1999-09 / 11 / 1999$ & $20.0 \mu \mathrm{g} / \mathrm{m}^{3}$ & $45.8 \mu \mathrm{g} / \mathrm{m}^{3}$ \\
\hline Winter & $01 / 13 / 2000-02 / 18 / 2000$ & $12.7 \mu \mathrm{g} / \mathrm{m}^{3}$ & $23.6 \mu \mathrm{g} / \mathrm{m}^{3}$ \\
\hline Summer & $07 / 17 / 2000-08 / 25 / 2000$ & $19.9 \mu \mathrm{g} / \mathrm{m}^{3}$ & $42.5 \mu \mathrm{g} / \mathrm{m}^{3}$ \\
\hline Summer & $06 / 30 / 2001-08 / 08 / 2001$ & $24.0 \mu \mathrm{g} / \mathrm{m}^{3}$ & $57.5 \mu \mathrm{g} / \mathrm{m}^{3}$ \\
\hline
\end{tabular}

At the LW site, the data suggests that there are no seasonal variations in $\mathrm{PM}_{10}$ mass concentrations at this site. At the $\mathrm{HB}$ site, the data suggests that $\mathrm{PM}_{10}$ mass concentrations may be higher during the summer season as compared with the winter season. However, the quantity of data from the HB site is not sufficient to strongly defend this conclusion.

\subsubsection{Presence of Trace Elements in $\mathrm{PM}_{2.5}$ and $\mathrm{PM}_{10}$ Samples - DRI Sampling Equipment - Site and Particle Size Comparisons}

For the $\mathrm{PM}_{2.5}$ and $\mathrm{PM}_{10}$ samples collected at the LW and HB sites with the DRI sampling equipment, calculate the "relative error" (defined as the ratio of the uncertainty value to the concentration) for each trace element - For comparison purposes, all $\mathrm{HB} \mathrm{PM}_{2.5}, \mathrm{HB} \mathrm{PM}_{10}$ and LW $\mathrm{PM}_{10}$ mass concentrations had a "relative error" of 0.2 or less; For comparison purposes, 99 percent of the LW $\mathrm{PM}_{2.5}$ mass concentrations had a "relative error" of 0.2 or less

$V=$ At least 80 percent of the samples classified in a particular category (HB $\mathrm{PM}_{2.5}, \mathrm{LW}$ $\mathrm{PM}_{2.5}, \mathrm{HB} \mathrm{PM}_{10}$ or $\mathrm{LW} \mathrm{PM}_{10}$ ) had a "relative error" (defined as the ratio of the uncertainty value to the concentration) of 0.2 or less -

\begin{tabular}{|c|c|c|c|c|}
\hline $\begin{array}{c}\text { Trace } \\
\text { Element }\end{array}$ & $\begin{array}{c}\mathrm{HB} \mathrm{PM}_{2.5} \\
\text { (58 samples) }\end{array}$ & $\begin{array}{c}\text { LW PM }_{2.5} \\
\text { (387 samples) }\end{array}$ & $\begin{array}{c}\text { HB PM }_{10} \\
\text { (8 samples) }\end{array}$ & $\begin{array}{c}\text { LW PM }_{10} \\
\text { (34 samples) }\end{array}$ \\
\hline \multicolumn{5}{|l|}{$\mathrm{Na}$} \\
\hline $\mathrm{Mg}$ & & & & \\
\hline \multicolumn{5}{|l|}{$\mathrm{Al}$} \\
\hline \multicolumn{5}{|l|}{$\mathrm{Si}$} \\
\hline $\mathrm{P}$ & & & & \\
\hline $\mathrm{S}$ & $\sqrt{ }$ & $\sqrt{ }$ & $\sqrt{ }$ & $\sqrt{ }$ \\
\hline $\mathrm{Cl}$ & $\sqrt{ }$ & $\sqrt{ }$ & & \\
\hline $\mathrm{K}$ & $\sqrt{ }$ & $\sqrt{ }$ & & \\
\hline
\end{tabular}




\begin{tabular}{|c|c|c|c|c|}
\hline $\begin{array}{c}\text { Trace } \\
\text { Element }\end{array}$ & $\begin{array}{c}\mathrm{HB} \mathrm{PM}_{2.5} \\
\text { (58 samples) }\end{array}$ & $\begin{array}{c}\text { LW PM }_{2.5} \\
\text { (387 samples) }\end{array}$ & $\begin{array}{c}\mathrm{HB} \mathrm{PM}_{10} \\
\text { (8 samples) }\end{array}$ & $\begin{array}{c}\text { LW PM }_{10} \\
\text { (34 samples) }\end{array}$ \\
\hline $\mathrm{Ca}$ & & & $\sqrt{ }$ & $\sqrt{ }$ \\
\hline \multicolumn{5}{|l|}{$\mathrm{Ti}$} \\
\hline \multicolumn{5}{|l|}{$\mathrm{V}$} \\
\hline \multicolumn{5}{|l|}{$\mathrm{Cr}$} \\
\hline \multicolumn{5}{|l|}{$\mathrm{Mn}$} \\
\hline $\mathrm{Fe}$ & $\sqrt{ }$ & $\sqrt{ }$ & $\sqrt{ }$ & $\sqrt{ }$ \\
\hline \multicolumn{5}{|l|}{ Co } \\
\hline \multicolumn{5}{|l|}{$\mathrm{Ni}$} \\
\hline \multicolumn{5}{|l|}{$\mathrm{Cu}$} \\
\hline $\mathrm{Zn}$ & & & $\sqrt{ }$ & $\sqrt{ }$ \\
\hline $\mathrm{Ga}$ & & & $\sqrt{ }$ & \\
\hline \multicolumn{5}{|l|}{ As } \\
\hline \multicolumn{5}{|l|}{$\mathrm{Se}$} \\
\hline \multicolumn{5}{|l|}{$\mathrm{Br}$} \\
\hline \multicolumn{5}{|l|}{$\mathrm{Rb}$} \\
\hline \multicolumn{5}{|l|}{$\mathrm{Sr}$} \\
\hline \multicolumn{5}{|l|}{$\bar{Y}$} \\
\hline \multicolumn{5}{|l|}{$\mathrm{Zr}$} \\
\hline \multicolumn{5}{|l|}{ Mo } \\
\hline $\mathrm{Pd}$ & & & $\sqrt{ }$ & \\
\hline \multicolumn{5}{|l|}{$\mathrm{Ag}$} \\
\hline \multicolumn{5}{|l|}{$\mathrm{Cd}$} \\
\hline \multicolumn{5}{|l|}{$\ln$} \\
\hline \multicolumn{5}{|l|}{$\mathrm{Sn}$} \\
\hline \multicolumn{5}{|l|}{$\mathrm{Sb}$} \\
\hline \multicolumn{5}{|l|}{$\mathrm{Ba}$} \\
\hline \multicolumn{5}{|l|}{$\mathrm{La}$} \\
\hline$\overline{\mathrm{Au}}$ & & & $\sqrt{ }$ & \\
\hline $\mathrm{Hg}$ & & & $\sqrt{ }$ & \\
\hline \multicolumn{5}{|l|}{$\mathrm{TI}$} \\
\hline \multicolumn{5}{|l|}{$\mathrm{Pb}$} \\
\hline$U$ & & & & \\
\hline
\end{tabular}




\subsection{CONCLUSIONS}

\subsection{Summary of Findings}

The following can be concluded from the findings presented above (this summary was previously presented in the most recent semi-annual technical report):

\section{Samples Collected During the Background Sampling Periods}

- $\quad$ The data collected during the background sampling periods suggests that $\mathrm{PM}_{2.5}$ mass concentrations are statistically the same at the LW, HB and MO sites.

- $\quad$ The data collected during the background sampling periods show that the overall average $\mathrm{PM}_{2.5}$ mass concentrations measured at the $\mathrm{HB}, \mathrm{LW}$ and $\mathrm{MO}$ sites are very nearly equal to the promulgated annual standard of $15 \mu \mathrm{g} / \mathrm{m}^{3}$ but far less than the 24-hour standard of $65 \mu \mathrm{g} / \mathrm{m}^{3}$.

- $\quad$ The data collected during the background sampling periods suggests that LW PM 10 mass concentrations are statistically greater than the HB $\mathrm{PM}_{10}$ mass concentrations.

- $\quad$ The data collected during the background sampling periods show that the overall average $\mathrm{PM}_{10}$ mass concentrations measured at the $\mathrm{HB}$ and $\mathrm{LW}$ sites are far less than the promulgated annual standard of $50 \mu \mathrm{g} / \mathrm{m}^{3}$ and the 24-hour standard of $150 \mu \mathrm{g} / \mathrm{m}^{3}$.

\section{Samples Collected During the Intensive Sampling Periods}

- During the summer months, diurnal variations of $\mathrm{LW} \mathrm{PM}_{2.5}$ and $\mathrm{PM}_{10}$ mass concentrations were observed. The changes in concentrations from one 6-hour measurement period to the following 6-hour measurement period were not statistically significant except for $\mathrm{PM}_{10}$ (increase from 0000-0600 to 0600-1200, likely due to inputs from automotive sources during the morning hours).

- $\quad$ During the winter months, diurnal variations of $\mathrm{LW} \mathrm{PM}_{2.5}$ and $\mathrm{PM}_{10}$ mass concentrations were observed. The changes in concentrations from one 6-hour measurement period to the following 6-hour measurement period were not statistically significant except for (i) $\mathrm{PM}_{2.5}$ and $\mathrm{PM}_{10}$ (increase from 0000-0600 to 0600-1200, likely due to inputs from automotive sources during the morning hours and decreases in the atmospheric mixing height during nighttime hours) and (ii) $\mathrm{PM}_{2.5}$ and $\mathrm{PM}_{10}$ (decrease from 0600-1200 to 1200-1800, likely due to increases in the atmospheric mixing height during daytime hours).

- $\quad$ At the LW site, the data suggests that $\mathrm{PM}_{2.5}$ mass concentrations are usually higher during the summer season as compared with the winter season, although other factors (e.g., local sources and weather) apparently contribute in a manner sufficient to obfuscate the seasonal pattern. At the $\mathrm{HB}$ site, the data strongly suggests that $\mathrm{PM}_{2.5}$ mass concentrations are higher during the summer season as compared with the winter season, which is likely due to the occurrence of photochemical activity. There is insufficient 
quantity of data from the $\mathrm{MO}$ site to deduce any seasonal variations in $\mathrm{PM}_{2.5}$ mass concentrations at this site.

- At the LW site, the data suggests that there are no seasonal variations in $\mathrm{PM}_{10}$ mass concentrations at this site. At the $\mathrm{HB}$ site, the data suggests that $\mathrm{PM}_{10}$ mass concentrations may be higher during the summer season as compared with the winter season. However, the quantity of data from the HB site is not sufficient to strongly defend this conclusion.

\subsection{Implications}

Historically, regions within the UORV that were initially designated to be in non-attainment with the $\mathrm{PM}_{10}$ ambient air standards were primarily localized industrial areas (e.g., Clairton, PA). As such, the SIPs for these areas focused on controlling air emissions from selected industrial facilities in an attempt to obtain attainment status with respect to the 24-hour $\mathrm{PM}_{10}$ standard (there were no regions within the UORV that were designated to be in non-attainment with respect to the annual $\mathrm{PM}_{10}$ standard). By comparison, the data obtained as part of the UORVP suggests that many regions within the UORV may be designated as non-attainment with respect to the annual $\mathrm{PM}_{2.5}$ standard. If this is realized, then the SIPs will likely mandate reducing air emissions of $\mathrm{PM}_{2.5}$ and/or its precursor gases from a large number of stationary, mobile and area sources that are located within a large geographical area. It should be noted that the UORV states (OH, PA and WV) submitted to the U.S. EPA in February 2004 a list of areas (counties) recommended to be designated to be in non-attainment with the $\mathrm{PM}_{2.5}$ standards (please refer to

the following reference links: http://www.epa.gov/pmdesignations/regions/region3.htm and http://www.epa.gov/pmdesignations/regions/region5.htm). The U.S. EPA intends to rule upon the state recommendations later this year. 


\subsection{ACKNOWLEDGEMENTS}

The authors would like to acknowledge funding on this project under NETL Contract No. DEAC26-98FT40456 and support from our colleagues at Desert Research Institute and Ohio University at Athens who are subcontractors on this project. 


\section{U.S. DEPARTMENT OF ENERGY \\ NATIONAL ENERGY TECHNOLOGY LABORATORY - PITTSBURGH, PA SEMI-ANNUAL TECHNICAL PROGRESS REPORT \\ OCTOBER 1, 2003 THROUGH MARCH 31, 2004}

Figure 1

Location of the UORVP Air Monitoring Sites and Neighboring Coal-Fired Electric Utility Plants

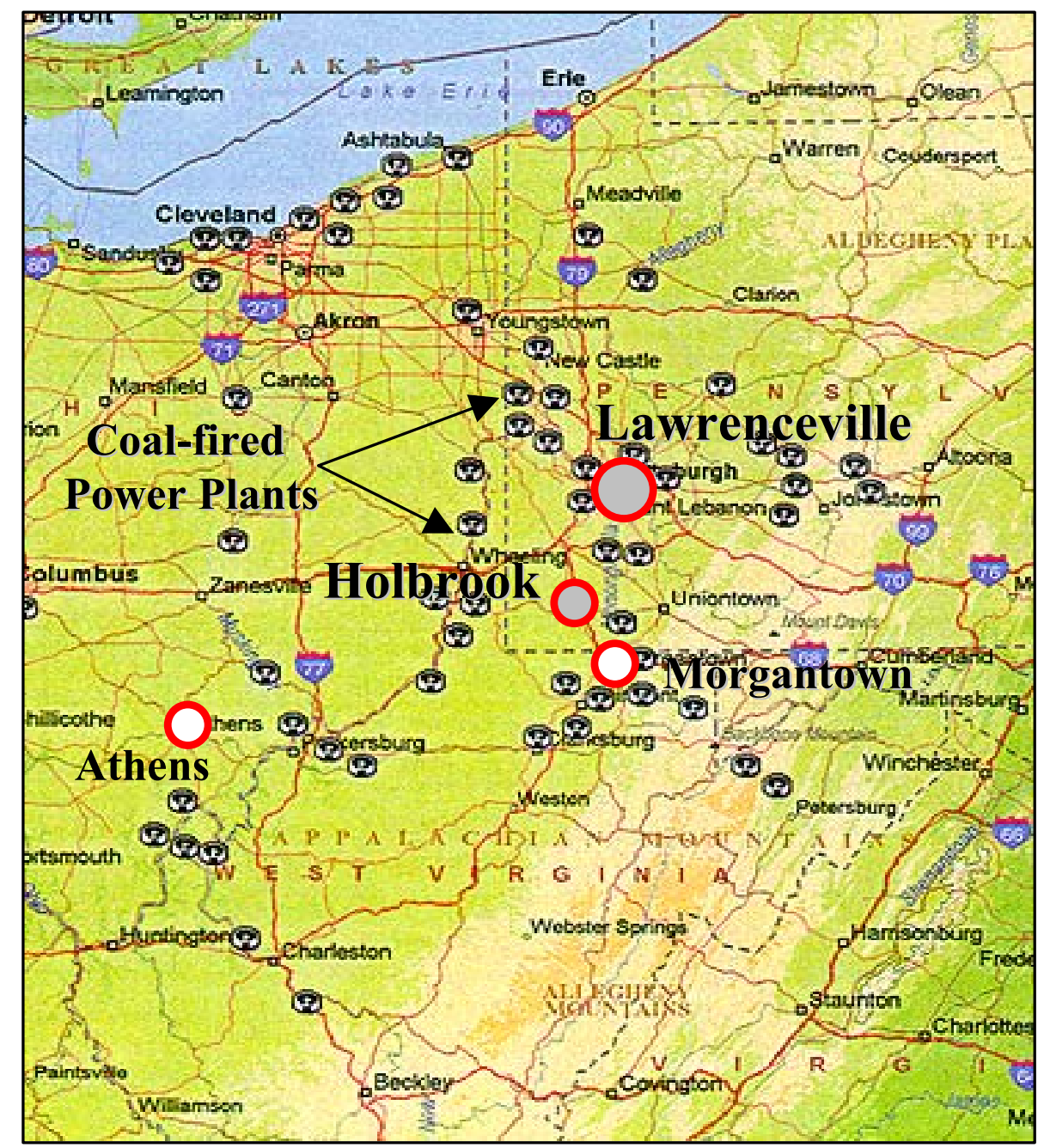




\section{U.S. DEPARTMENT OF ENERGY \\ NATIONAL ENERGY TECHNOLOGY LABORATORY - PITTSBURGH, PA \\ SEMI-ANNUAL TECHNICAL PROGRESS REPORT \\ OCTOBER 1, 2003 THROUGH MARCH 31, 2004}

FIGURE 2

\section{UORVP ORGANIZATION CHART}

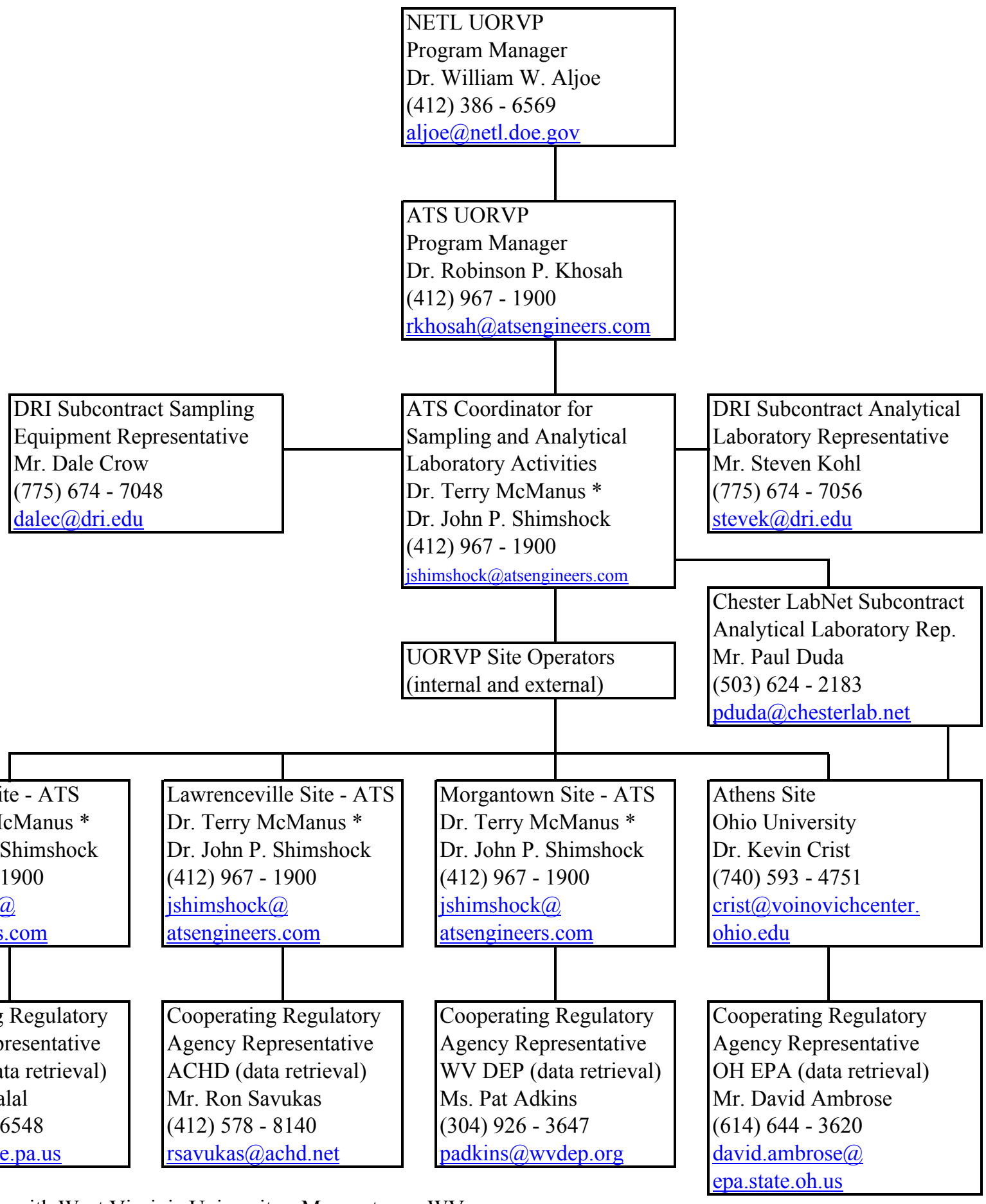

*: Currently with West Virginia University - Morgantown, WV 


\section{U.S. DEPARTMENT OF ENERGY \\ NATIONAL ENERGY TECHNOLOGY LABORATORY - PITTSBURGH, PA SEMI-ANNUAL TECHNICAL PROGRESS REPORT OCTOBER 1, 2003 THROUGH MARCH 31, 2004}

TABLE 1

\section{SUMMARY OF THE AMBIENT AIR PARAMETERS AND THE ASSOCIATED MEASUREMENT TECHNIQUES DEPLOYED AT EACH OF THE FOUR UORVP SITES}

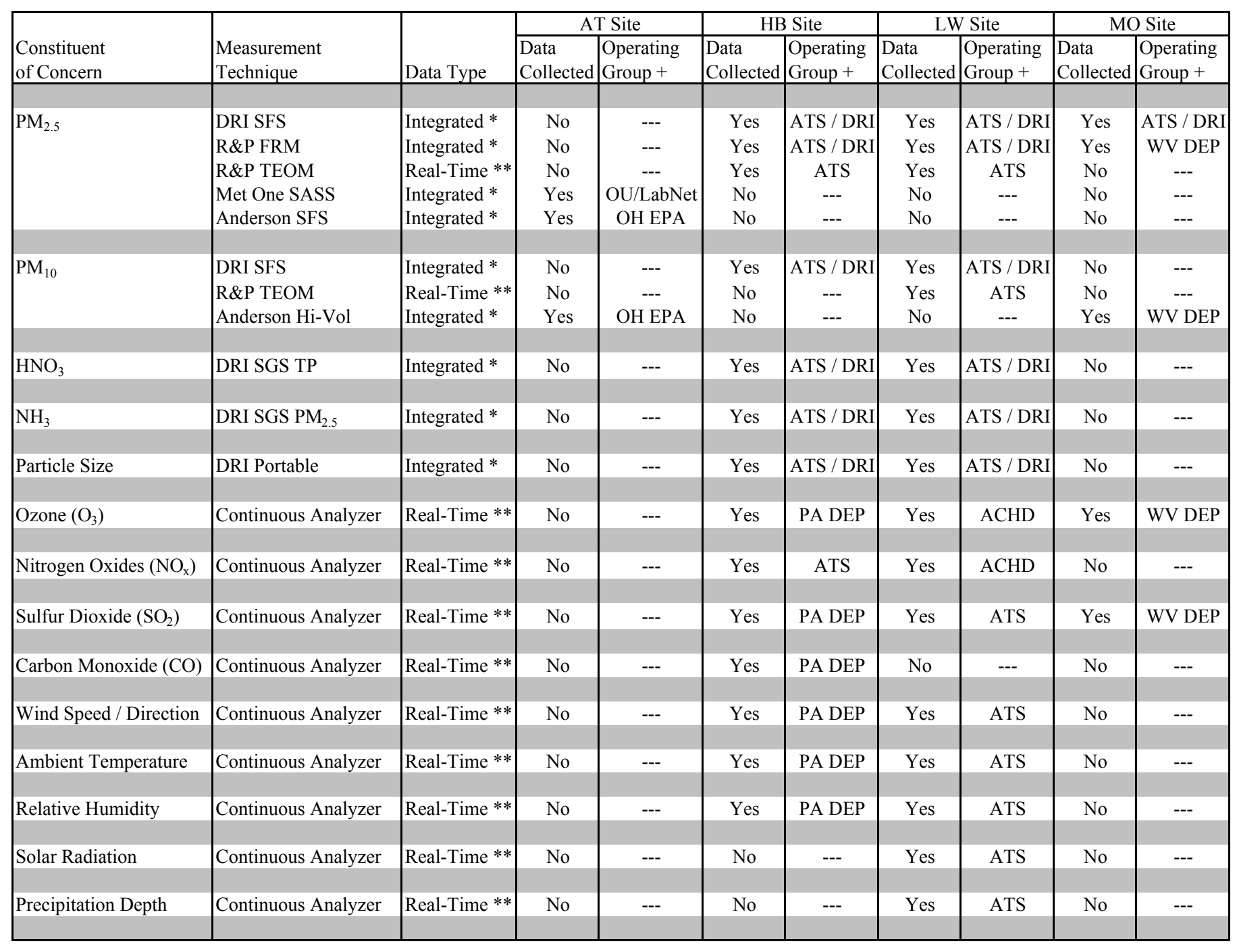

$\begin{array}{ll}\begin{array}{ll}\text { Legend } \\ \text { DRI }\end{array} & \begin{array}{l}\text { Desert Research Institute } \\ \text { SFS }\end{array} \\ \text { SGS TP } & \text { Sequential Filter Sampler } \\ & \text { Sequential Gas Sampler with } \\ \text { Total Particulate Matter Inlet Particle Sizer } & \text { Sequential Gas Sampler with } \\ \text { SGS PM2.5 } & \text { PM2.5 Inlet Particle Sizer } \\ \text { Portable } & \text { Filter Sampler with PM2.5 Inlet Particle Sizer } \\ \text { Anderson } & \text { Sierra (Thermal) Anderson Instruments } \\ \text { OU } & \text { Ohio University } \\ \text { LabNet } & \text { Chester LabNet }\end{array}$

R\&P Rupprecht \& Patashnick Co., Inc.

FRM Federal Reference Method

Hi-Vol High volume air sampler

Met One Met One Instruments, Inc.

TEOM Tapered Element Oscillating Microbalance - Series 1400a

SASS Spiral Aerosol Speciation Sampler

* Over time

** Continuous

$+\quad$ If two groups are listed (e.g., ATS / DRI), the first group performed the field sampling while the second group performed the analytical laboratory analyses 


\section{U.S. DEPARTMENT OF ENERGY}

NATIONAL ENERGY TECHNOLOGY LABORATORY - PITTSBURGH, PA

SEMI-ANNUAL TECHNICAL PROGRESS REPORT

OCTOBER 1, 2003 THROUGH MARCH 31, 2004

TABLE 2

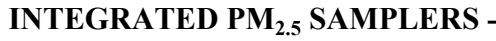

SAMPLING AND ANALYSIS LOG

\begin{tabular}{|c|c|c|c|c|c|c|c|c|c|}
\hline \multirow[b]{2}{*}{$\begin{array}{l}\text { Sampling } \\
\text { Period Type } \\
\end{array}$} & \multirow[b]{2}{*}{ Site ID } & \multirow[b]{2}{*}{$\begin{array}{l}\text { Measurement } \\
\text { Technique }\end{array}$} & \multirow[b]{2}{*}{$\begin{array}{l}\text { Start } \\
\text { Date }\end{array}$} & \multirow[b]{2}{*}{$\begin{array}{l}\text { Stop } \\
\text { Date }\end{array}$} & \multirow[b]{2}{*}{\begin{tabular}{|l} 
Sampling \\
Frequency
\end{tabular}} & \multirow{2}{*}{$\begin{array}{l}\text { Nominal } \\
\text { Sampling } \\
\text { Duration (hrs) }\end{array}$} & \multirow{2}{*}{$\begin{array}{l}\text { No. of } \\
\text { Samples } \\
\text { Collected } *\end{array}$} & \multicolumn{2}{|c|}{ No. Samples Analyzed ** } \\
\hline & & & & & & & & Mass & $\begin{array}{l}\text { Chemical } \\
\text { Constituents }\end{array}$ \\
\hline \multirow[t]{4}{*}{$\begin{array}{l}\text { Intensive } \\
\text { (winter) }\end{array}$} & $\begin{array}{l}\text { AT } \\
\text { AT } \\
\end{array}$ & $\begin{array}{l}\text { Anderson SFS } \\
\text { Met One SASS } \\
\end{array}$ & & & Every 3rd Day & 24 & & & \\
\hline & $\begin{array}{l}\mathrm{HB} \\
\mathrm{HB}\end{array}$ & $\begin{array}{l}\text { DRI SFS } \\
\text { R\&P FRM }\end{array}$ & $\begin{array}{l}2 / 17 / 1999 \\
2 / 17 / 1999\end{array}$ & $\begin{array}{l}2 / 28 / 1999 \\
2 / 28 / 1999\end{array}$ & $\begin{array}{l}\text { Once per day } \\
\text { Every 6th Day }\end{array}$ & $\begin{array}{l}24 \\
24\end{array}$ & 12 & 11 & $\begin{array}{l}10 \\
2\end{array}$ \\
\hline & $\begin{array}{l}\text { LW } \\
\text { LW }\end{array}$ & $\begin{array}{l}\text { DRI SFS } \\
\text { R\&P FRM }\end{array}$ & $\begin{array}{l}2 / 17 / 1999 \\
2 / 17 / 1999 \\
\end{array}$ & $\begin{array}{l}2 / 28 / 1999 \\
2 / 28 / 1999 \\
\end{array}$ & $\begin{array}{l}4 \text { times per day } \\
\text { Every 6th Day }\end{array}$ & \begin{tabular}{|l}
6 \\
24 \\
\end{tabular} & 48 & 46 & $\begin{array}{l}37 \\
2\end{array}$ \\
\hline & $\begin{array}{l}\mathrm{MO} \\
\mathrm{MO}\end{array}$ & $\begin{array}{l}\text { DRI SFS } \\
\text { R\&P FRM }\end{array}$ & $2 / 17 / 1999$ & $2 / 28 / 1999$ & $\begin{array}{l}\text { Every 3rd Day } \\
\text { Every 3rd Day }\end{array}$ & $\begin{array}{l}24 \\
24\end{array}$ & 0 & 0 & 0 \\
\hline \multirow[t]{4}{*}{ Background } & $\begin{array}{l}\text { AT } \\
\text { AT } \\
\end{array}$ & $\begin{array}{l}\text { Anderson SFS } \\
\text { Met One SASS } \\
\end{array}$ & & & Every 3rd Day & 24 & & & \\
\hline & \begin{tabular}{|l}
$\mathrm{HB}$ \\
$\mathrm{HB}$ \\
\end{tabular} & $\begin{array}{l}\text { DRI SFS } \\
\text { R\&P FRM } \\
\end{array}$ & $\begin{array}{l}3 / 1 / 1999 \\
3 / 1 / 1999 \\
\end{array}$ & \begin{tabular}{|l|}
$7 / 29 / 1999$ \\
$7 / 29 / 1999$ \\
\end{tabular} & $\begin{array}{l}\text { Every 6th Day } \\
\text { Every 6th Day }\end{array}$ & \begin{tabular}{|l|}
24 \\
24 \\
\end{tabular} & 26 & 26 & $\begin{array}{l}7 \\
7 \\
\end{array}$ \\
\hline & $\begin{array}{l}\mathrm{LW} \\
\mathrm{LW}\end{array}$ & $\begin{array}{l}\text { DRI SFS } \\
\text { R\&P FRM }\end{array}$ & \begin{tabular}{|l|}
$3 / 1 / 1999$ \\
$3 / 1 / 1999$
\end{tabular} & $\begin{array}{l}7 / 29 / 1999 \\
7 / 29 / 1999\end{array}$ & $\begin{array}{l}\text { Every 6th Day } \\
\text { Every 6th Day }\end{array}$ & $\begin{array}{l}24 \\
24\end{array}$ & 26 & 26 & $\begin{array}{l}7 \\
7\end{array}$ \\
\hline & $\begin{array}{l}\mathrm{MO} \\
\mathrm{MO}\end{array}$ & $\begin{array}{l}\text { DRI SFS } \\
\text { R\&P FRM } \\
\end{array}$ & $3 / 1 / 1999$ & $7 / 29 / 1999$ & $\begin{array}{l}\text { Every 6th Day } \\
\text { Every 3rd Day }\end{array}$ & $\begin{array}{l}24 \\
24\end{array}$ & 0 & 0 & 0 \\
\hline \multirow[t]{4}{*}{$\begin{array}{l}\text { Intensive } \\
\text { (summer) }\end{array}$} & $\begin{array}{l}\text { AT } \\
\text { AT } \\
\end{array}$ & $\begin{array}{l}\text { Anderson SFS } \\
\text { Met One SASS }\end{array}$ & & & Every 3rd Day & 24 & & & \\
\hline & $\begin{array}{l}\mathrm{HB} \\
\mathrm{HB} \\
\end{array}$ & \begin{tabular}{|l|} 
DRI SFS \\
R\&P FRM \\
\end{tabular} & $\begin{array}{l}/ 3 / 1999 \\
8 / 3 / 1999 \\
\end{array}$ & $\begin{array}{l}9 / 11 / 1999 \\
9 / 11 / 1999 \\
\end{array}$ & $\begin{array}{l}\text { Once per day } \\
\text { Every 6th Day }\end{array}$ & $\begin{array}{l}24 \\
24 \\
\end{array}$ & 40 & 39 & $\begin{array}{l}11 \\
7 \\
\end{array}$ \\
\hline & \begin{tabular}{|l}
$\mathrm{LW}$ \\
$\mathrm{LW}$ \\
\end{tabular} & \begin{tabular}{|l} 
DRI SFS \\
R\&P FRM \\
\end{tabular} & $\begin{array}{l}8 / 3 / 1999 \\
8 / 3 / 1999 \\
\end{array}$ & \begin{tabular}{|l|}
$9 / 11 / 1999$ \\
$9 / 11 / 1999$ \\
\end{tabular} & $\begin{array}{l}4 \text { times per day } \\
\text { Every 6th Day }\end{array}$ & \begin{tabular}{|l|}
6 \\
24 \\
\end{tabular} & 160 & 154 & \begin{tabular}{|l}
40 \\
2 \\
\end{tabular} \\
\hline & $\begin{array}{l}\mathrm{MO} \\
\mathrm{MO}\end{array}$ & $\begin{array}{l}\text { DRI SFS } \\
\text { R\&P FRM } \\
\end{array}$ & $8 / 21 / 1999$ & $9 / 11 / 1999$ & $\begin{array}{l}\text { Every 3rd Day } \\
\text { Every 3rd Day }\end{array}$ & \begin{tabular}{|l|}
24 \\
24 \\
\end{tabular} & 8 & 5 & 0 \\
\hline \multirow[t]{4}{*}{ Background } & $\begin{array}{l}\text { AT } \\
\text { AT }\end{array}$ & $\begin{array}{l}\text { Anderson SFS } \\
\text { Met One SASS } \\
\end{array}$ & & & Every 3rd Day & 24 & & & \\
\hline & \begin{tabular}{|l}
$\mathrm{HB}$ \\
$\mathrm{HB}$ \\
\end{tabular} & \begin{tabular}{|l} 
DRI SFS \\
R\&P FRM \\
\end{tabular} & \begin{tabular}{|l|}
$9 / 15 / 1999$ \\
$9 / 15 / 1999$ \\
\end{tabular} & $\begin{array}{l}1 / 7 / 2000 \\
1 / 7 / 2000 \\
\end{array}$ & $\begin{array}{l}\text { Every 6th Day } \\
\text { Every 6th Day }\end{array}$ & $\begin{array}{l}24 \\
24 \\
\end{array}$ & 20 & 17 & 0 \\
\hline & $\begin{array}{l}\text { LW } \\
\text { LW }\end{array}$ & $\begin{array}{l}\text { DRI SFS } \\
\text { R\&P FRM }\end{array}$ & $\begin{array}{l}9 / 15 / 1999 \\
9 / 15 / 1999\end{array}$ & $\begin{array}{l}1 / 7 / 2000 \\
1 / 7 / 2000\end{array}$ & $\begin{array}{l}\text { Every 6th Day } \\
\text { Every 6th Day }\end{array}$ & $\begin{array}{l}24 \\
24\end{array}$ & 20 & 20 & 0 \\
\hline & $\begin{array}{l}\mathrm{MO} \\
\mathrm{MO}\end{array}$ & $\begin{array}{l}\text { DRI SFS } \\
\text { R\&P FRM } \\
\end{array}$ & $9 / 15 / 1999$ & $1 / 7 / 2000$ & $\begin{array}{l}\text { Every 6th Day } \\
\text { Every 3rd Day }\end{array}$ & $\begin{array}{l}24 \\
24 \\
\end{array}$ & 21 & 20 & 0 \\
\hline
\end{tabular}




\section{U.S. DEPARTMENT OF ENERGY}

NATIONAL ENERGY TECHNOLOGY LABORATORY - PITTSBURGH, PA

SEMI-ANNUAL TECHNICAL PROGRESS REPORT

OCTOBER 1, 2003 THROUGH MARCH 31, 2004

TABLE 2

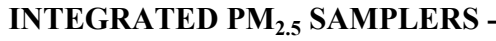

SAMPLING AND ANALYSIS LOG

\begin{tabular}{|c|c|c|c|c|c|c|c|c|c|}
\hline \multirow[b]{2}{*}{$\begin{array}{l}\text { Sampling } \\
\text { Period Type }\end{array}$} & \multirow[b]{2}{*}{ Site ID } & \multirow[b]{2}{*}{$\begin{array}{l}\text { Measurement } \\
\text { Technique }\end{array}$} & \multirow[b]{2}{*}{$\begin{array}{l}\text { Start } \\
\text { Date }\end{array}$} & \multirow[b]{2}{*}{$\begin{array}{l}\text { Stop } \\
\text { Date }\end{array}$} & \multirow[b]{2}{*}{\begin{tabular}{|l} 
Sampling \\
Frequency
\end{tabular}} & \multirow{2}{*}{\begin{tabular}{|l} 
Nominal \\
Sampling \\
Duration (hrs)
\end{tabular}} & \multirow{2}{*}{$\begin{array}{l}\text { No. of } \\
\text { Samples } \\
\text { Collected } *\end{array}$} & \multicolumn{2}{|c|}{ No. Samples Analyzed ** } \\
\hline & & & & & & & & Mass & $\begin{array}{l}\text { Chemical } \\
\text { Constituents }\end{array}$ \\
\hline \multirow[t]{4}{*}{$\begin{array}{l}\text { Intensive } \\
\text { (winter) }\end{array}$} & $\begin{array}{l}\text { AT } \\
\text { AT } \\
\end{array}$ & $\begin{array}{l}\text { Anderson SFS } \\
\text { Met One SASS } \\
\end{array}$ & & & Every 3rd Day & 24 & & & \\
\hline & $\begin{array}{l}\mathrm{HB} \\
\mathrm{HB}\end{array}$ & $\begin{array}{l}\text { DRI SFS } \\
\text { R\&P FRM }\end{array}$ & $\begin{array}{l}1 / 12 / 2000 \\
1 / 12 / 2000\end{array}$ & $\begin{array}{l}2 / 18 / 2000 \\
2 / 18 / 2000\end{array}$ & $\begin{array}{l}\text { Once per day } \\
\text { Every 6th Day }\end{array}$ & $\begin{array}{l}24 \\
24\end{array}$ & 38 & 35 & $\begin{array}{l}11 \\
6\end{array}$ \\
\hline & $\begin{array}{l}\text { LW } \\
\text { LW }\end{array}$ & $\begin{array}{l}\text { DRI SFS } \\
\text { R\&P FRM }\end{array}$ & $\begin{array}{l}1 / 12 / 2000 \\
1 / 12 / 2000\end{array}$ & $\begin{array}{l}2 / 18 / 2000 \\
2 / 18 / 2000\end{array}$ & $\begin{array}{l}4 \text { times per day } \\
\text { Every 6th Day }\end{array}$ & \begin{tabular}{|l}
6 \\
24 \\
\end{tabular} & 152 & 140 & $\begin{array}{l}38 \\
6 \\
\end{array}$ \\
\hline & $\begin{array}{l}\mathrm{MO} \\
\mathrm{MO}\end{array}$ & \begin{tabular}{|l} 
DRI SFS \\
R\&P FRM \\
\end{tabular} & $1 / 13 / 2000$ & $2 / 18 / 2000$ & $\begin{array}{l}\text { Every 3rd Day } \\
\text { Every 3rd Day }\end{array}$ & $\begin{array}{l}24 \\
24\end{array}$ & 13 & 8 & 0 \\
\hline \multirow[t]{4}{*}{ Background } & $\begin{array}{l}\text { AT } \\
\text { AT } \\
\end{array}$ & $\begin{array}{l}\text { Anderson SFS } \\
\text { Met One SASS } \\
\end{array}$ & & & Every 3rd Day & 24 & & & \\
\hline & $\begin{array}{l}\mathrm{HB} \\
\mathrm{HB}\end{array}$ & \begin{tabular}{|l|} 
DRI SFS \\
R\&P FRM \\
\end{tabular} & $\begin{array}{l}2 / 24 / 2000 \\
2 / 24 / 2000\end{array}$ & $\begin{array}{l}7 / 11 / 2000 \\
7 / 11 / 2000 \\
\end{array}$ & $\begin{array}{l}\text { Every 6th Day } \\
\text { Every 6th Day }\end{array}$ & $\begin{array}{l}24 \\
24\end{array}$ & 23 & 16 & 1 \\
\hline & $\begin{array}{l}\mathrm{LW} \\
\mathrm{LW}\end{array}$ & $\begin{array}{l}\text { DRI SFS } \\
\text { R\&P FRM }\end{array}$ & $\begin{array}{l}2 / 24 / 2000 \\
2 / 24 / 2000\end{array}$ & $\begin{array}{l}7 / 11 / 2000 \\
7 / 11 / 2000\end{array}$ & $\begin{array}{l}\text { Every 6th Day } \\
\text { Every 6th Day }\end{array}$ & $\begin{array}{l}24 \\
24\end{array}$ & 23 & 22 & 2 \\
\hline & $\begin{array}{l}\mathrm{MO} \\
\mathrm{MO}\end{array}$ & \begin{tabular}{|l} 
DRI SFS \\
R\&P FRM \\
\end{tabular} & $2 / 24 / 2000$ & $7 / 11 / 2000$ & $\begin{array}{l}\text { Every 6th Day } \\
\text { Every 3rd Day }\end{array}$ & $\begin{array}{l}24 \\
24 \\
\end{array}$ & 21 & 19 & 0 \\
\hline \multirow[t]{4}{*}{$\begin{array}{l}\text { Intensive } \\
\text { (summer) }\end{array}$} & $\begin{array}{l}\text { AT } \\
\text { AT } \\
\end{array}$ & $\begin{array}{l}\text { Anderson SFS } \\
\text { Met One SASS } \\
\end{array}$ & & & Every 3rd Day & 24 & & & \\
\hline & $\begin{array}{l}\mathrm{HB} \\
\mathrm{HB} \\
\end{array}$ & $\begin{array}{l}\text { DRI SFS } \\
\text { R\&P FRM } \\
\end{array}$ & $\begin{array}{l}7 / 17 / 2000 \\
7 / 17 / 2000 \\
\end{array}$ & $\begin{array}{l}8 / 25 / 2000 \\
8 / 25 / 2000 \\
\end{array}$ & $\begin{array}{l}\text { Once per day } \\
\text { Every 6th Day }\end{array}$ & $\begin{array}{l}24 \\
24 \\
\end{array}$ & 40 & 39 & $\begin{array}{l}16 \\
7 \\
\end{array}$ \\
\hline & \begin{tabular}{|l}
$\mathrm{LW}$ \\
$\mathrm{LW}$ \\
\end{tabular} & \begin{tabular}{|l} 
DRI SFS \\
R\&P FRM \\
\end{tabular} & $\begin{array}{l}7 / 17 / 2000 \\
7 / 17 / 2000 \\
\end{array}$ & $\begin{array}{l}8 / 25 / 2000 \\
8 / 25 / 2000 \\
\end{array}$ & $\begin{array}{l}4 \text { times per day } \\
\text { Every 6th Day }\end{array}$ & \begin{tabular}{|l|}
6 \\
24 \\
\end{tabular} & 160 & 149 & $\begin{array}{l}60 \\
7 \\
\end{array}$ \\
\hline & $\begin{array}{l}\mathrm{MO} \\
\mathrm{MO}\end{array}$ & \begin{tabular}{|l} 
DRI SFS \\
R\&P FRM \\
\end{tabular} & $7 / 17 / 2000$ & $8 / 25 / 2000$ & $\begin{array}{l}\text { Every 3rd Day } \\
\text { Every 3rd Day }\end{array}$ & $\begin{array}{l}24 \\
24 \\
\end{array}$ & 14 & 12 & 0 \\
\hline \multirow[t]{4}{*}{ Background } & $\begin{array}{l}\text { AT } \\
\text { AT }\end{array}$ & $\begin{array}{l}\text { Anderson SFS } \\
\text { Met One SASS } \\
\end{array}$ & & & Every 3rd Day & 24 & & & \\
\hline & \begin{tabular}{|l}
$\mathrm{HB}$ \\
$\mathrm{HB}$ \\
\end{tabular} & \begin{tabular}{|l|} 
DRI SFS \\
R\&P FRM \\
\end{tabular} & \begin{tabular}{|l|}
$8 / 28 / 2000$ \\
$8 / 28 / 2000$ \\
\end{tabular} & \begin{tabular}{|l|}
$6 / 24 / 2001$ \\
$6 / 24 / 2001$ \\
\end{tabular} & $\begin{array}{l}\text { Every 6th Day } \\
\text { Every 6th Day }\end{array}$ & $\begin{array}{l}24 \\
24 \\
\end{array}$ & 51 & 38 & $\begin{array}{l}2 \\
22 \\
\end{array}$ \\
\hline & $\begin{array}{l}\text { LW } \\
\text { LW }\end{array}$ & $\begin{array}{l}\text { DRI SFS } \\
\text { R\&P FRM }\end{array}$ & $\begin{array}{l}8 / 28 / 2000 \\
8 / 28 / 2000\end{array}$ & $\begin{array}{l}6 / 24 / 2001 \\
6 / 24 / 2001\end{array}$ & $\begin{array}{l}\text { Every 6th Day } \\
\text { Every 6th Day }\end{array}$ & $\begin{array}{l}24 \\
24\end{array}$ & 51 & 50 & $\begin{array}{l}2 \\
21\end{array}$ \\
\hline & $\begin{array}{l}\mathrm{MO} \\
\mathrm{MO}\end{array}$ & $\begin{array}{l}\text { DRI SFS } \\
\text { R\&P FRM } \\
\end{array}$ & $8 / 28 / 2000$ & $6 / 24 / 2001$ & $\begin{array}{l}\text { Every 6th Day } \\
\text { Every 3rd Day }\end{array}$ & $\begin{array}{l}24 \\
24 \\
\end{array}$ & 50 & 43 & 0 \\
\hline
\end{tabular}




\section{U.S. DEPARTMENT OF ENERGY}

NATIONAL ENERGY TECHNOLOGY LABORATORY - PITTSBURGH, PA

SEMI-ANNUAL TECHNICAL PROGRESS REPORT

OCTOBER 1, 2003 THROUGH MARCH 31, 2004

TABLE 2

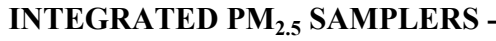

SAMPLING AND ANALYSIS LOG

\begin{tabular}{|c|c|c|c|c|c|c|c|c|c|}
\hline \multirow[b]{2}{*}{$\begin{array}{l}\text { Sampling } \\
\text { Period Type }\end{array}$} & \multirow[b]{2}{*}{ Site ID } & \multirow[b]{2}{*}{$\begin{array}{l}\text { Measurement } \\
\text { Technique }\end{array}$} & \multirow[b]{2}{*}{$\begin{array}{l}\text { Start } \\
\text { Date }\end{array}$} & \multirow[b]{2}{*}{$\begin{array}{l}\text { Stop } \\
\text { Date }\end{array}$} & \multirow[b]{2}{*}{$\begin{array}{l}\text { Sampling } \\
\text { Frequency }\end{array}$} & \multirow{2}{*}{$\begin{array}{l}\text { Nominal } \\
\text { Sampling } \\
\text { Duration (hrs) }\end{array}$} & \multirow{2}{*}{$\begin{array}{l}\text { No. of } \\
\text { Samples } \\
\text { Collected * } \\
\end{array}$} & \multicolumn{2}{|c|}{ No. Samples Analyzed ** } \\
\hline & & & & & & & & Mass & \begin{tabular}{|l|} 
Chemical \\
Constituents
\end{tabular} \\
\hline \multirow[t]{4}{*}{$\begin{array}{l}\text { Intensive } \\
\text { (summer) }\end{array}$} & $\begin{array}{l}\text { AT } \\
\text { AT }\end{array}$ & $\begin{array}{l}\text { Anderson SFS } \\
\text { Met One SASS } \\
\end{array}$ & & & Every 3rd Day & 24 & & & \\
\hline & $\begin{array}{l}\mathrm{HB} \\
\mathrm{HB}\end{array}$ & $\begin{array}{l}\text { DRI SFS } \\
\text { R\&P FRM }\end{array}$ & $\begin{array}{l}6 / 30 / 2001 \\
6 / 30 / 2001\end{array}$ & $\begin{array}{l}8 / 8 / 2001 \\
8 / 8 / 2001\end{array}$ & $\begin{array}{l}\text { Once per day } \\
\text { Every 6th Day }\end{array}$ & $\begin{array}{l}24 \\
24\end{array}$ & 40 & 36 & $\begin{array}{l}21 \\
9\end{array}$ \\
\hline & \begin{tabular}{|l}
$\mathrm{LW}$ \\
$\mathrm{LW}$ \\
\end{tabular} & \begin{tabular}{|l} 
DRI SFS \\
R\&P FRM \\
\end{tabular} & $\begin{array}{l}6 / 30 / 2001 \\
6 / 30 / 2001 \\
\end{array}$ & $\begin{array}{l}8 / 8 / 2001 \\
8 / 8 / 2001 \\
\end{array}$ & $\begin{array}{l}4 \text { times per day } \\
\text { Every 6th Day }\end{array}$ & $\begin{array}{l}6 \\
24 \\
\end{array}$ & 160 & 156 & $\begin{array}{l}83 \\
9 \\
\end{array}$ \\
\hline & $\begin{array}{l}\mathrm{MO} \\
\mathrm{MO}\end{array}$ & $\begin{array}{l}\text { DRI SFS } \\
\text { R\&P FRM } \\
\end{array}$ & $6 / 30 / 2001$ & $8 / 5 / 2001$ & $\begin{array}{l}\text { Every 3rd Day } \\
\text { Every 3rd Day }\end{array}$ & $\begin{array}{l}24 \\
24 \\
\end{array}$ & 14 & 12 & 0 \\
\hline \multirow[t]{4}{*}{$\begin{array}{l}\text { Intensive } \\
\text { (winter) }\end{array}$} & $\begin{array}{l}\mathrm{AT} \\
\mathrm{AT}\end{array}$ & $\begin{array}{l}\text { Anderson SFS } \\
\text { Met One SASS } \\
\end{array}$ & & & Every 3rd Day & 24 & & & \\
\hline & $\begin{array}{l}\mathrm{HB} \\
\mathrm{HB}\end{array}$ & $\begin{array}{l}\text { DRI SFS } \\
\text { R\&P FRM }\end{array}$ & \begin{tabular}{|l}
$1 / 2 / 2002$ \\
$1 / 2 / 2002$
\end{tabular} & $\begin{array}{l}1 / 22 / 2002 \\
1 / 22 / 2002\end{array}$ & $\begin{array}{l}\text { Once per day } \\
\text { Every 6th Day }\end{array}$ & $\begin{array}{l}24 \\
24\end{array}$ & 21 & 21 & 0 \\
\hline & $\begin{array}{l}\mathrm{LW} \\
\mathrm{LW}\end{array}$ & $\begin{array}{l}\text { DRI SFS } \\
\text { R\&P FRM }\end{array}$ & $\begin{array}{l}1 / 2 / 2002 \\
1 / 2 / 2002\end{array}$ & $\begin{array}{l}1 / 22 / 2002 \\
1 / 22 / 2002\end{array}$ & $\begin{array}{l}\text { Once per day } \\
\text { Every 6th Day }\end{array}$ & $\begin{array}{l}24 \\
24\end{array}$ & 21 & 21 & 0 \\
\hline & $\begin{array}{l}\mathrm{MO} \\
\mathrm{MO}\end{array}$ & $\begin{array}{l}\text { DRI SFS } \\
\text { R\&P FRM } \\
\end{array}$ & $1 / 2 / 2002$ & $1 / 22 / 2002$ & $\begin{array}{l}\text { Every 3rd Day } \\
\text { Every 3rd Day }\end{array}$ & $\begin{array}{l}24 \\
24 \\
\end{array}$ & 0 & 0 & 0 \\
\hline \multirow[t]{4}{*}{$\begin{array}{l}\text { Intensive } \\
\text { (fall \& winter) }\end{array}$} & $\begin{array}{l}\text { AT } \\
\text { AT } \\
\end{array}$ & $\begin{array}{l}\text { Anderson SFS } \\
\text { Met One SASS }\end{array}$ & & & Every 3rd Day & 24 & & & \\
\hline & $\begin{array}{l}\mathrm{HB} \\
\mathrm{HB}\end{array}$ & $\begin{array}{l}\text { DRI SFS } \\
\text { R\&P FRM }\end{array}$ & $\begin{array}{l}10 / 1 / 2002 \\
10 / 1 / 2002\end{array}$ & $\begin{array}{l}2 / 28 / 2003 \\
2 / 28 / 2003\end{array}$ & $\begin{array}{l}\text { Once per day } \\
\text { Every 6th Day }\end{array}$ & $\begin{array}{l}24 \\
24\end{array}$ & 0 & 0 & 0 \\
\hline & \begin{tabular}{|l|}
$\mathrm{LW}$ \\
$\mathrm{LW}$ \\
\end{tabular} & \begin{tabular}{|l} 
DRI SFS \\
R\&P FRM \\
\end{tabular} & $\begin{array}{l}10 / 1 / 2002 \\
10 / 1 / 2002 \\
\end{array}$ & \begin{tabular}{|l|}
$2 / 28 / 2003$ \\
$2 / 28 / 2003$ \\
\end{tabular} & $\begin{array}{l}\text { Once per day } \\
\text { Every 6th Day }\end{array}$ & $\begin{array}{l}24 \\
24 \\
\end{array}$ & 164 & 164 & 164 \\
\hline & $\begin{array}{l}\mathrm{MO} \\
\mathrm{MO}\end{array}$ & $\begin{array}{l}\text { DRI SFS } \\
\text { R\&P FRM }\end{array}$ & $10 / 1 / 2002$ & $2 / 28 / 2003$ & $\begin{array}{l}\text { Every 3rd Day } \\
\text { Every 3rd Day }\end{array}$ & $\begin{array}{l}24 \\
24\end{array}$ & 0 & 0 & 0 \\
\hline & & & & & & & & & \\
\hline
\end{tabular}

*: $\quad$ Excludes Field Blanks and Missing Data

Blank entries denotes that the data were unavailable for this report
**: $\quad$ Excludes Field and Laboratory Blanks Chemical constituents include 38 elements (primarily metals), organic and elemental carbon, inorganic ions, artifact organic carbon and volatilized nitrate 


\section{U.S. DEPARTMENT OF ENERGY \\ NATIONAL ENERGY TECHNOLOGY LABORATORY - PITTSBURGH, PA SEMI-ANNUAL TECHNICAL PROGRESS REPORT \\ OCTOBER 1, 2003 THROUGH MARCH 31, 2004}

TABLE 3

INTEGRATED PM ${ }_{10}$ SAMPLERS -

SAMPLING AND ANALYSIS LOG

\begin{tabular}{|c|c|c|c|c|c|c|c|c|c|}
\hline \multirow[b]{2}{*}{$\begin{array}{l}\text { Sampling } \\
\text { Period Type }\end{array}$} & \multirow[b]{2}{*}{ Site ID } & \multirow[b]{2}{*}{$\begin{array}{l}\text { Measurement } \\
\text { Technique }\end{array}$} & \multirow[b]{2}{*}{$\begin{array}{l}\text { Start } \\
\text { Date }\end{array}$} & \multirow[b]{2}{*}{$\begin{array}{l}\text { Stop } \\
\text { Date }\end{array}$} & \multirow[b]{2}{*}{$\begin{array}{l}\text { Sampling } \\
\text { Frequency }\end{array}$} & \multirow{2}{*}{$\begin{array}{l}\text { Nominal } \\
\text { Sampling } \\
\text { Duration (hrs) } \\
\end{array}$} & \multirow{2}{*}{$\begin{array}{l}\text { No. of } \\
\text { Samples } \\
\text { Collected * }\end{array}$} & \multicolumn{2}{|c|}{ No. Samples Analyzed ** } \\
\hline & & & & & & & & Mass & \begin{tabular}{|l|} 
Chemical \\
Constituents
\end{tabular} \\
\hline $\begin{array}{l}\text { Intensive } \\
\text { (winter) }\end{array}$ & $\begin{array}{l}\text { AT } \\
\text { HB } \\
\text { LW } \\
\text { MO } \\
\end{array}$ & $\begin{array}{l}\text { Anderson Hi-Vol } \\
\text { DRI SFS } \\
\text { DRI SFS } \\
\text { Anderson Hi-Vol } \\
\end{array}$ & $\begin{array}{l}2 / 17 / 1999 \\
2 / 17 / 1999\end{array}$ & $\begin{array}{l}2 / 28 / 1999 \\
2 / 28 / 1999\end{array}$ & \begin{tabular}{|l|} 
Every 6 th Day \\
Once per day \\
4 times per day \\
Every 6 th Day \\
\end{tabular} & \begin{tabular}{|l|}
24 \\
24 \\
6 \\
24 \\
\end{tabular} & $\begin{array}{l}12 \\
48\end{array}$ & $\begin{array}{l}11 \\
45\end{array}$ & $\begin{array}{l}10 \\
38\end{array}$ \\
\hline Background & \begin{tabular}{|l} 
AT \\
HB \\
LW \\
MO
\end{tabular} & $\begin{array}{l}\text { Anderson Hi-Vol } \\
\text { DRI SFS } \\
\text { DRI SFS } \\
\text { Anderson Hi-Vol }\end{array}$ & $\begin{array}{l}3 / 1 / 1999 \\
3 / 1 / 1999\end{array}$ & $\begin{array}{l}7 / 29 / 1999 \\
7 / 29 / 1999\end{array}$ & $\begin{array}{l}\text { Every 6th Day } \\
\text { Every 6th Day } \\
\text { Every 6th Day } \\
\text { Every 6th Day } \\
\end{array}$ & \begin{tabular}{|l|}
24 \\
24 \\
24 \\
24 \\
\end{tabular} & $\begin{array}{l}26 \\
26\end{array}$ & $\begin{array}{l}26 \\
25\end{array}$ & 7 \\
\hline $\begin{array}{l}\text { Intensive } \\
\text { (summer) }\end{array}$ & $\begin{array}{l}\text { AT } \\
\text { HB } \\
\text { LW } \\
\text { MO }\end{array}$ & $\begin{array}{l}\text { Anderson Hi-Vol } \\
\text { DRI SFS } \\
\text { DRI SFS } \\
\text { Anderson Hi-Vol }\end{array}$ & $\begin{array}{l}8 / 3 / 1999 \\
8 / 3 / 1999\end{array}$ & $\begin{array}{l}9 / 11 / 1999 \\
9 / 11 / 1999\end{array}$ & $\begin{array}{l}\text { Every 6th Day } \\
\text { Once per day } \\
4 \text { times per day } \\
\text { Every 6th Day }\end{array}$ & \begin{tabular}{|l|}
24 \\
24 \\
6 \\
24
\end{tabular} & $\begin{array}{l}40 \\
160\end{array}$ & $\mid \begin{array}{l}40 \\
155\end{array}$ & $\begin{array}{l}0 \\
0\end{array}$ \\
\hline Background & \begin{tabular}{|l|} 
AT \\
HB \\
LW \\
MO \\
\end{tabular} & $\begin{array}{l}\text { Anderson Hi-Vol } \\
\text { DRI SFS } \\
\text { DRI SFS } \\
\text { Anderson Hi-Vol } \\
\end{array}$ & $\begin{array}{l}9 / 15 / 1999 \\
9 / 15 / 1999\end{array}$ & $\begin{array}{l}1 / 7 / 2000 \\
1 / 7 / 2000\end{array}$ & $\begin{array}{l}\text { Every 6th Day } \\
\text { Every 6th Day } \\
\text { Every 6th Day } \\
\text { Every 6th Day } \\
\end{array}$ & $\begin{array}{l}24 \\
24 \\
24 \\
24\end{array}$ & $\begin{array}{l}19 \\
20\end{array}$ & $\begin{array}{l}19 \\
20\end{array}$ & $\begin{array}{l}0 \\
0\end{array}$ \\
\hline $\begin{array}{l}\text { Intensive } \\
\text { (winter) }\end{array}$ & \begin{tabular}{|l} 
AT \\
HB \\
LW \\
MO
\end{tabular} & $\begin{array}{l}\text { Anderson Hi-Vol } \\
\text { DRI SFS } \\
\text { DRI SFS } \\
\text { Anderson Hi-Vol }\end{array}$ & $\begin{array}{l}1 / 12 / 2000 \\
1 / 12 / 2000\end{array}$ & $\begin{array}{l}2 / 18 / 2000 \\
2 / 18 / 2000\end{array}$ & $\begin{array}{l}\text { Every 6th Day } \\
\text { Once per day } \\
4 \text { times per day } \\
\text { Every 6th Day } \\
\end{array}$ & \begin{tabular}{|l}
24 \\
24 \\
6 \\
24 \\
\end{tabular} & $\begin{array}{l}38 \\
147\end{array}$ & $\begin{array}{l}35 \\
132\end{array}$ & $\begin{array}{l}0 \\
0\end{array}$ \\
\hline Background & \begin{tabular}{|l} 
AT \\
HB \\
LW \\
MO \\
\end{tabular} & $\begin{array}{l}\text { Anderson Hi-Vol } \\
\text { DRI SFS } \\
\text { DRI SFS } \\
\text { Anderson Hi-Vol } \\
\end{array}$ & $\begin{array}{l}2 / 24 / 2000 \\
2 / 24 / 2000\end{array}$ & $\begin{array}{l}7 / 11 / 2000 \\
7 / 11 / 2000\end{array}$ & \begin{tabular}{|l|} 
Every 6th Day \\
Every 6th Day \\
Every 6th Day \\
Every 6th Day \\
\end{tabular} & \begin{tabular}{|l|}
24 \\
24 \\
24 \\
24 \\
\end{tabular} & $\begin{array}{l}22 \\
23\end{array}$ & $\begin{array}{l}20 \\
21\end{array}$ & $\begin{array}{l}0 \\
0\end{array}$ \\
\hline $\begin{array}{l}\text { Intensive } \\
\text { (summer) }\end{array}$ & $\begin{array}{l}\text { AT } \\
\text { HB } \\
\text { LW } \\
\text { MO }\end{array}$ & $\begin{array}{l}\text { Anderson Hi-Vol } \\
\text { DRI SFS } \\
\text { DRI SFS } \\
\text { Anderson Hi-Vol }\end{array}$ & $\begin{array}{l}7 / 17 / 2000 \\
7 / 17 / 2000\end{array}$ & $\begin{array}{l}8 / 25 / 2000 \\
8 / 25 / 2000\end{array}$ & $\begin{array}{l}\text { Every 6th Day } \\
\text { Once per day } \\
4 \text { times per day } \\
\text { Every 6th Day }\end{array}$ & $\begin{array}{l}24 \\
24 \\
6 \\
24\end{array}$ & $\begin{array}{l}40 \\
160\end{array}$ & $\begin{array}{l}39 \\
153\end{array}$ & $\begin{array}{l}0 \\
0\end{array}$ \\
\hline
\end{tabular}




\section{U.S. DEPARTMENT OF ENERGY \\ NATIONAL ENERGY TECHNOLOGY LABORATORY - PITTSBURGH, PA \\ SEMI-ANNUAL TECHNICAL PROGRESS REPORT \\ OCTOBER 1, 2003 THROUGH MARCH 31, 2004}

TABLE 3

INTEGRATED PM ${ }_{10}$ SAMPLERS -
SAMPLING AND ANALYSIS LOG

\begin{tabular}{|c|c|c|c|c|c|c|c|c|c|}
\hline \multirow[b]{2}{*}{$\begin{array}{l}\text { Sampling } \\
\text { Period Type }\end{array}$} & \multirow[b]{2}{*}{ Site ID } & \multirow[b]{2}{*}{$\begin{array}{l}\text { Measurement } \\
\text { Technique }\end{array}$} & \multirow[b]{2}{*}{$\begin{array}{l}\text { Start } \\
\text { Date }\end{array}$} & \multirow[b]{2}{*}{$\begin{array}{l}\text { Stop } \\
\text { Date }\end{array}$} & \multirow[b]{2}{*}{$\begin{array}{l}\text { Sampling } \\
\text { Frequency }\end{array}$} & \multirow{2}{*}{$\begin{array}{l}\text { Nominal } \\
\text { Sampling } \\
\text { Duration (hrs) }\end{array}$} & \multirow{2}{*}{\begin{tabular}{|l} 
No. of \\
Samples \\
Collected *
\end{tabular}} & \multicolumn{2}{|c|}{ No. Samples Analyzed ** } \\
\hline & & & & & & & & Mass & \begin{tabular}{|l|} 
Chemical \\
Constituents
\end{tabular} \\
\hline Background & $\begin{array}{l}\text { AT } \\
\text { HB } \\
\text { LW } \\
\text { MO }\end{array}$ & $\begin{array}{l}\text { Anderson } \mathrm{Hi}-\mathrm{Vol} \\
\text { DRI SFS } \\
\text { DRI SFS } \\
\text { Anderson Hi-Vol }\end{array}$ & $\begin{array}{l}8 / 28 / 2000 \\
8 / 28 / 2000\end{array}$ & $\begin{array}{l}6 / 24 / 2001 \\
6 / 24 / 2001\end{array}$ & $\begin{array}{l}\text { Every 6th Day } \\
\text { Every 6th Day } \\
\text { Every 6th Day } \\
\text { Every 6th Day }\end{array}$ & $\begin{array}{l}24 \\
24 \\
24 \\
24\end{array}$ & $\begin{array}{l}51 \\
51\end{array}$ & $\begin{array}{l}51 \\
46\end{array}$ & $\begin{array}{l}0 \\
0\end{array}$ \\
\hline $\begin{array}{l}\text { Intensive } \\
\text { (summer) }\end{array}$ & $\begin{array}{l}\text { AT } \\
\text { HB } \\
\text { LW } \\
\text { MO }\end{array}$ & $\begin{array}{l}\text { Anderson Hi-Vol } \\
\text { DRI SFS } \\
\text { DRI SFS } \\
\text { Anderson Hi-Vol }\end{array}$ & $\begin{array}{l}6 / 30 / 2001 \\
6 / 30 / 2001\end{array}$ & $\begin{array}{l}8 / 8 / 2001 \\
8 / 8 / 2001\end{array}$ & $\begin{array}{l}\text { Every 6th Day } \\
\text { Once per day } \\
4 \text { times per day } \\
\text { Every 6th Day }\end{array}$ & \begin{tabular}{|l}
24 \\
24 \\
6 \\
24
\end{tabular} & $\begin{array}{l}40 \\
160\end{array}$ & $\begin{array}{l}40 \\
145\end{array}$ & $\begin{array}{l}0 \\
0\end{array}$ \\
\hline $\begin{array}{l}\text { Intensive } \\
\text { (winter) }\end{array}$ & \begin{tabular}{|l} 
AT \\
HB \\
LW \\
MO
\end{tabular} & $\begin{array}{l}\text { Anderson Hi-Vol } \\
\text { DRI SFS } \\
\text { DRI SFS } \\
\text { Anderson Hi-Vol }\end{array}$ & $\begin{array}{l}1 / 2 / 2002 \\
1 / 2 / 2002\end{array}$ & $\begin{array}{l}1 / 22 / 2002 \\
1 / 22 / 2002\end{array}$ & \begin{tabular}{|l} 
Every 6th Day \\
Once per day \\
Once per day \\
Every 6th Day
\end{tabular} & $\begin{array}{l}24 \\
24 \\
24 \\
24\end{array}$ & $\begin{array}{l}0 \\
0\end{array}$ & $\begin{array}{l}0 \\
0\end{array}$ & $\begin{array}{l}0 \\
0\end{array}$ \\
\hline $\begin{array}{l}\text { Intensive } \\
\text { (fall \& winter) }\end{array}$ & $\begin{array}{l}\text { AT } \\
\text { LW } \\
\text { HB } \\
\text { MO }\end{array}$ & $\begin{array}{l}\text { Anderson Hi-Vol } \\
\text { DRI SFS } \\
\text { DRI SFS } \\
\text { Anderson Hi-Vol }\end{array}$ & $\begin{array}{l}10 / 1 / 2002 \\
10 / 1 / 2002\end{array}$ & $\begin{array}{l}2 / 28 / 2003 \\
2 / 28 / 2003\end{array}$ & $\begin{array}{l}\text { Every 6th Day } \\
\text { Once per day } \\
\text { Once per day } \\
\text { Every 6th Day }\end{array}$ & $\begin{array}{l}24 \\
24 \\
24 \\
24\end{array}$ & $\begin{array}{l}0 \\
0\end{array}$ & $\begin{array}{l}0 \\
0\end{array}$ & $\begin{array}{l}0 \\
0\end{array}$ \\
\hline
\end{tabular}

*: $\quad$ Excludes Field Blanks and Missing Data

Blank entries denotes that the data were unavailable for this report
**:

Excludes Field and Laboratory Blanks Chemical constituents include 38 elements (primarily metals), organic and elemental carbon, inorganic ions, artifact organic carbon and volatilized nitrate 


\section{U.S. DEPARTMENT OF ENERGY \\ NATIONAL ENERGY TECHNOLOGY LABORATORY - PITTSBURGH, PA \\ SEMI-ANNUAL TECHNICAL PROGRESS REPORT \\ OCTOBER 1, 2003 THROUGH MARCH 31, 2004}

TABLE 4

INTEGRATED NITRIC ACID $\left(\mathrm{HNO}_{3}\right)$ GAS SAMPLER -
SAMPLING AND ANALYSIS LOG

\begin{tabular}{|c|c|c|c|c|c|c|c|c|}
\hline $\begin{array}{l}\text { Sampling } \\
\text { Period Type }\end{array}$ & Site ID & $\begin{array}{l}\text { Measurement } \\
\text { Technique }\end{array}$ & $\begin{array}{l}\text { Start } \\
\text { Date }\end{array}$ & $\begin{array}{l}\text { Stop } \\
\text { Date }\end{array}$ & $\begin{array}{l}\text { Sampling } \\
\text { Frequency }\end{array}$ & \begin{tabular}{|l} 
Nominal \\
Sampling \\
Duration (hrs)
\end{tabular} & $\begin{array}{l}\text { No. of } \\
\text { Samples } \\
\text { Collected * }\end{array}$ & \begin{tabular}{|l|} 
No. of \\
Samples \\
Analyzed $* *$ \\
\end{tabular} \\
\hline $\begin{array}{l}\text { Intensive } \\
\text { (winter) }\end{array}$ & $\begin{array}{l}\text { HB } \\
\text { LW }\end{array}$ & \begin{tabular}{|l|} 
DRI SGS TP \\
DRI SGS TP
\end{tabular} & \begin{tabular}{|l}
$2 / 17 / 1999$ \\
$2 / 17 / 1999$ \\
\end{tabular} & \begin{tabular}{|l|}
$2 / 28 / 1999$ \\
$2 / 28 / 1999$ \\
\end{tabular} & $\begin{array}{l}\text { Once per day } \\
4 \text { times per day } \\
\end{array}$ & $\begin{array}{l}24 \\
6 \\
\end{array}$ & $\begin{array}{l}12 \\
48\end{array}$ & $\begin{array}{l}10 \\
38 \\
\end{array}$ \\
\hline Background & $\begin{array}{l}\text { HB } \\
\text { LW }\end{array}$ & $\begin{array}{l}\text { DRI SGS TP } \\
\text { DRI SGS TP }\end{array}$ & $\begin{array}{l}3 / 1 / 1999 \\
3 / 1 / 1999\end{array}$ & $\begin{array}{l}7 / 29 / 1999 \\
7 / 29 / 1999\end{array}$ & $\begin{array}{l}\text { Every 6th Day } \\
\text { Every 6th Day }\end{array}$ & $\begin{array}{l}24 \\
24\end{array}$ & $\begin{array}{l}26 \\
26\end{array}$ & $\begin{array}{l}7 \\
7\end{array}$ \\
\hline $\begin{array}{l}\text { Intensive } \\
\text { (summer) }\end{array}$ & $\begin{array}{l}\mathrm{HB} \\
\mathrm{LW} \\
\end{array}$ & \begin{tabular}{|l|} 
DRI SGS TP \\
DRI SGS TP \\
\end{tabular} & \begin{tabular}{|l|}
$8 / 3 / 1999$ \\
$8 / 3 / 1999$ \\
\end{tabular} & \begin{tabular}{|l|}
$9 / 11 / 1999$ \\
$9 / 11 / 1999$ \\
\end{tabular} & \begin{tabular}{|l|} 
Once per day \\
4 times per day \\
\end{tabular} & $\begin{array}{l}24 \\
6 \\
\end{array}$ & \begin{tabular}{|l|}
40 \\
160 \\
\end{tabular} & $\begin{array}{l}11 \\
41 \\
\end{array}$ \\
\hline Background & $\begin{array}{l}\mathrm{HB} \\
\mathrm{LW} \\
\end{array}$ & \begin{tabular}{|l|} 
DRI SGS TP \\
DRI SGS TP \\
\end{tabular} & \begin{tabular}{|l|}
$9 / 15 / 1999$ \\
$9 / 15 / 1999$ \\
\end{tabular} & \begin{tabular}{|l|}
$1 / 7 / 2000$ \\
$1 / 7 / 2000$ \\
\end{tabular} & \begin{tabular}{|l|} 
Every 6th Day \\
Every 6th Day
\end{tabular} & $\begin{array}{l}24 \\
24 \\
\end{array}$ & $\begin{array}{l}20 \\
20 \\
\end{array}$ & $\begin{array}{l}0 \\
0 \\
\end{array}$ \\
\hline $\begin{array}{l}\text { Intensive } \\
\text { (winter) }\end{array}$ & $\begin{array}{l}\text { HB } \\
\text { LW }\end{array}$ & $\begin{array}{l}\text { DRI SGS TP } \\
\text { DRI SGS TP } \\
\end{array}$ & \begin{tabular}{|l|}
$1 / 12 / 2000$ \\
$1 / 12 / 2000$ \\
\end{tabular} & $\begin{array}{l}2 / 18 / 2000 \\
2 / 18 / 2000 \\
\end{array}$ & \begin{tabular}{|l|} 
Once per day \\
4 times per day \\
\end{tabular} & $\begin{array}{l}24 \\
6 \\
\end{array}$ & $\begin{array}{l}38 \\
152 \\
\end{array}$ & $\begin{array}{l}12 \\
46 \\
\end{array}$ \\
\hline Background & $\begin{array}{l}\text { HB } \\
\text { LW }\end{array}$ & $\begin{array}{l}\text { DRI SGS TP } \\
\text { DRI SGS TP }\end{array}$ & $\begin{array}{l}2 / 24 / 2000 \\
2 / 24 / 2000\end{array}$ & $\begin{array}{l}7 / 11 / 2000 \\
7 / 11 / 2000 \\
\end{array}$ & \begin{tabular}{|l|} 
Every 6th Day \\
Every 6th Day
\end{tabular} & $\begin{array}{l}24 \\
24 \\
\end{array}$ & $\begin{array}{l}24 \\
24 \\
\end{array}$ & $\begin{array}{l}2 \\
2 \\
\end{array}$ \\
\hline $\begin{array}{l}\text { Intensive } \\
\text { (summer) }\end{array}$ & $\begin{array}{l}\mathrm{HB} \\
\mathrm{LW}\end{array}$ & $\begin{array}{l}\text { DRI SGS TP } \\
\text { DRI SGS TP }\end{array}$ & $\begin{array}{l}7 / 17 / 2000 \\
7 / 17 / 2000 \\
\end{array}$ & $\begin{array}{l}8 / 25 / 2000 \\
8 / 25 / 2000 \\
\end{array}$ & $\begin{array}{l}\text { Once per day } \\
4 \text { times per day } \\
\end{array}$ & $\begin{array}{l}24 \\
6 \\
\end{array}$ & \begin{tabular}{|l|}
40 \\
160
\end{tabular} & $\begin{array}{l}19 \\
66\end{array}$ \\
\hline Background & \begin{tabular}{|l} 
HB \\
LW
\end{tabular} & \begin{tabular}{|l|} 
DRI SGS TP \\
DRI SGS TP
\end{tabular} & $\begin{array}{l}8 / 28 / 2000 \\
8 / 28 / 2000 \\
\end{array}$ & \begin{tabular}{|l|}
$6 / 24 / 2001$ \\
$6 / 24 / 2001$ \\
\end{tabular} & \begin{tabular}{|l} 
Every 6th Day \\
Every 6th Day
\end{tabular} & $\begin{array}{l}24 \\
24\end{array}$ & $\begin{array}{l}51 \\
51\end{array}$ & $\begin{array}{l}3 \\
5 \\
\end{array}$ \\
\hline $\begin{array}{l}\text { Intensive } \\
\text { (summer) }\end{array}$ & $\begin{array}{l}\text { HB } \\
\text { LW } \\
\end{array}$ & \begin{tabular}{|l|} 
DRI SGS TP \\
DRI SGS TP \\
\end{tabular} & \begin{tabular}{|l|}
$6 / 30 / 2001$ \\
$6 / 30 / 2001$ \\
\end{tabular} & $\begin{array}{l}8 / 8 / 2001 \\
8 / 8 / 2001 \\
\end{array}$ & \begin{tabular}{|l|} 
Once per day \\
4 times per day
\end{tabular} & $\begin{array}{l}24 \\
6 \\
\end{array}$ & \begin{tabular}{|l|}
40 \\
160 \\
\end{tabular} & $\begin{array}{l}20 \\
80\end{array}$ \\
\hline $\begin{array}{l}\text { Intensive } \\
\text { (winter) }\end{array}$ & $\begin{array}{l}\text { HB } \\
\text { LW }\end{array}$ & $\begin{array}{l}\text { DRI SGS TP } \\
\text { DRI SGS TP }\end{array}$ & \begin{tabular}{|l|}
$1 / 2 / 2002$ \\
$1 / 2 / 2002$
\end{tabular} & $\begin{array}{l}1 / 22 / 2002 \\
1 / 22 / 2002\end{array}$ & $\begin{array}{l}\text { Once per day } \\
\text { Once per day }\end{array}$ & $\begin{array}{l}24 \\
24\end{array}$ & $\begin{array}{l}21 \\
21\end{array}$ & $\begin{array}{l}0 \\
0\end{array}$ \\
\hline $\begin{array}{l}\text { Intensive } \\
\text { (fall \& winter) }\end{array}$ & $\begin{array}{l}\mathrm{HB} \\
\mathrm{LW} \\
\end{array}$ & \begin{tabular}{|l|} 
DRI SGS TP \\
DRI SGS TP \\
\end{tabular} & \begin{tabular}{|l|}
$10 / 1 / 2002$ \\
$10 / 1 / 2002$ \\
\end{tabular} & $\begin{array}{l}2 / 28 / 2003 \\
2 / 28 / 2003 \\
\end{array}$ & $\begin{array}{l}\text { Once per day } \\
\text { Once per day }\end{array}$ & $\begin{array}{l}24 \\
24 \\
\end{array}$ & $\begin{array}{l}0 \\
0 \\
\end{array}$ & $\begin{array}{l}0 \\
0 \\
\end{array}$ \\
\hline
\end{tabular}

*: $\quad$ Excludes Field Blanks $\quad$ **: $\quad$ Excludes Field and Laboratory Blanks 


\section{U.S. DEPARTMENT OF ENERGY}

NATIONAL ENERGY TECHNOLOGY LABORATORY - PITTSBURGH, PA SEMI-ANNUAL TECHNICAL PROGRESS REPORT OCTOBER 1, 2003 THROUGH MARCH 31, 2004

TABLE 5

INTEGRATED AMMONIA $\left(\mathrm{NH}_{3}\right)$ GAS SAMPLER SAMPLING AND ANALYSIS LOG

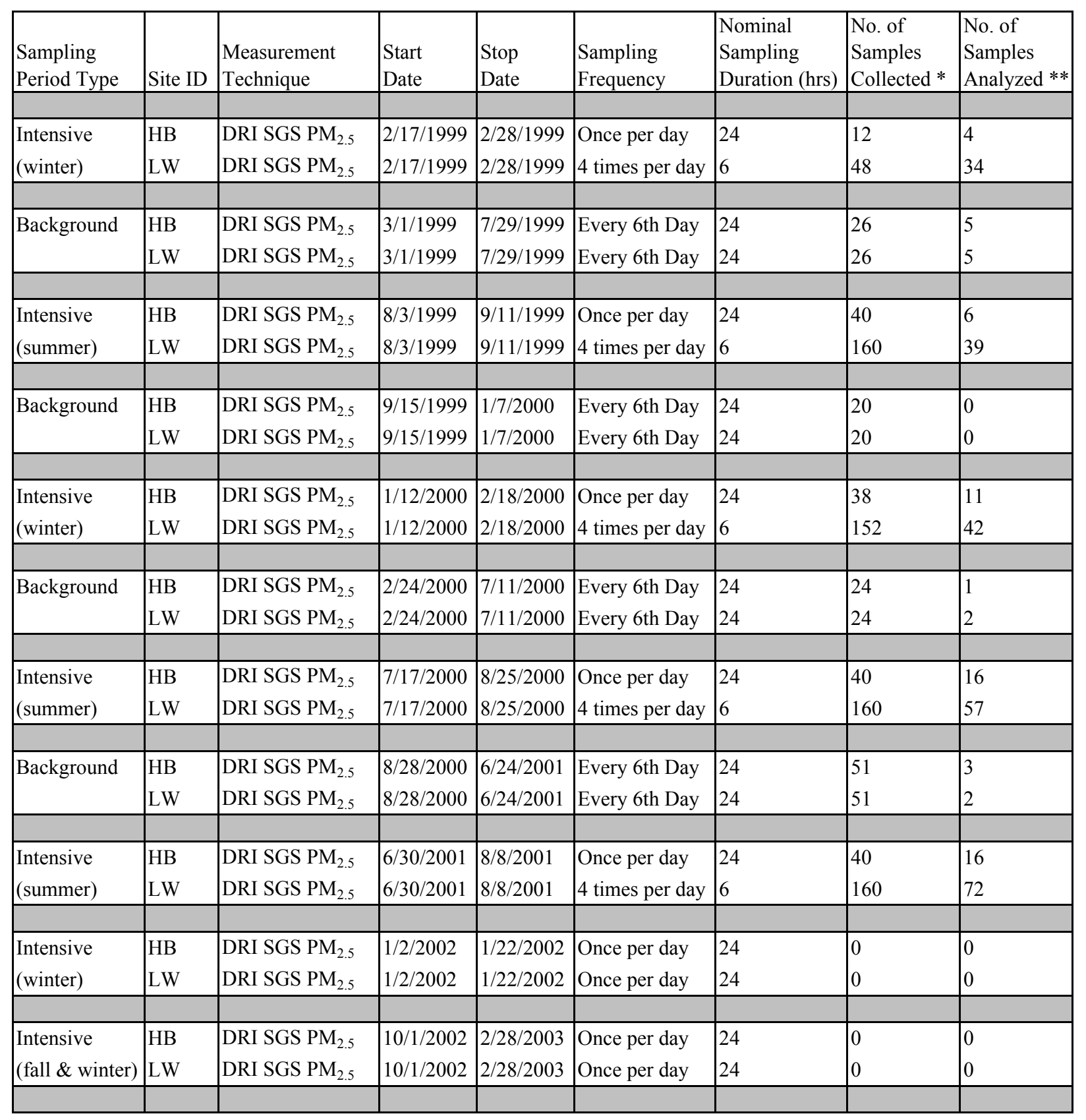

*: $\quad$ Excludes Field Blanks

**: $\quad$ Excludes Field and Laboratory Blanks 


\section{U.S. DEPARTMENT OF ENERGY \\ NATIONAL ENERGY TECHNOLOGY LABORATORY - PITTSBURGH, PA \\ SEMI-ANNUAL TECHNICAL PROGRESS REPORT \\ OCTOBER 1, 2003 THROUGH MARCH 31, 2004}

TABLE 6

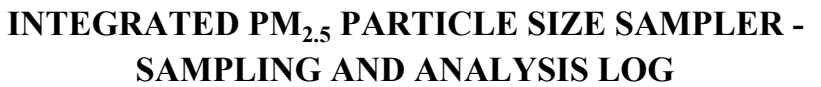

\begin{tabular}{|c|c|c|c|c|c|c|c|c|}
\hline $\begin{array}{l}\text { Sampling } \\
\text { Period Type }\end{array}$ & Site ID & $\begin{array}{l}\text { Measurement } \\
\text { Technique }\end{array}$ & $\begin{array}{l}\text { Start } \\
\text { Date }\end{array}$ & $\begin{array}{l}\text { Stop } \\
\text { Date }\end{array}$ & $\begin{array}{l}\text { Sampling } \\
\text { Frequency }\end{array}$ & \begin{tabular}{|l|} 
Nominal \\
Sampling \\
Duration (hrs)
\end{tabular} & \begin{tabular}{|l} 
No. of \\
Samples \\
Collected * \\
\end{tabular} & \begin{tabular}{|l|} 
No. of \\
Samples \\
Analyzed $* *$ \\
\end{tabular} \\
\hline $\begin{array}{l}\begin{array}{l}\text { Intensive } \\
\text { (winter) }\end{array} \\
\end{array}$ & $\begin{array}{l}\text { HB } \\
\text { LW } \\
\end{array}$ & \begin{tabular}{|l|} 
DRI Portable \\
DRI Portable
\end{tabular} & \begin{tabular}{|l|}
$2 / 17 / 1999$ \\
$2 / 17 / 1999$ \\
\end{tabular} & \begin{tabular}{|l|}
$2 / 28 / 1999$ \\
$2 / 28 / 1999$ \\
\end{tabular} & $\begin{array}{l}\text { Once per day } \\
4 \text { times per day } \\
\end{array}$ & $\begin{array}{l}24 \\
6 \\
\end{array}$ & $\begin{array}{l}12 \\
48 \\
\end{array}$ & $\begin{array}{l}0 \\
0 \\
\end{array}$ \\
\hline Background & $\begin{array}{l}\mathrm{HB} \\
\mathrm{LW} \\
\end{array}$ & \begin{tabular}{|l|} 
DRI Portable \\
DRI Portable \\
\end{tabular} & \begin{tabular}{|l|}
$3 / 1 / 1999$ \\
$3 / 1 / 1999$ \\
\end{tabular} & \begin{tabular}{|l|}
$7 / 29 / 1999$ \\
$7 / 29 / 1999$ \\
\end{tabular} & \begin{tabular}{|l|} 
Every 6th Day \\
Every 6th Day \\
\end{tabular} & $\begin{array}{l}24 \\
24 \\
\end{array}$ & $\begin{array}{l}26 \\
26 \\
\end{array}$ & $\begin{array}{l}0 \\
0 \\
\end{array}$ \\
\hline \begin{tabular}{|l}
$\begin{array}{l}\text { Intensive } \\
\text { (summer) }\end{array}$ \\
\end{tabular} & $\begin{array}{l}\text { HB } \\
\text { LW }\end{array}$ & $\begin{array}{l}\text { DRI Portable } \\
\text { DRI Portable }\end{array}$ & \begin{tabular}{|l|}
$8 / 3 / 1999$ \\
$8 / 3 / 1999$ \\
\end{tabular} & \begin{tabular}{|l}
$9 / 11 / 1999$ \\
$9 / 11 / 1999$ \\
\end{tabular} & $\begin{array}{l}\text { Once per day } \\
4 \text { times per day }\end{array}$ & $\begin{array}{l}24 \\
6 \\
\end{array}$ & \begin{tabular}{|l}
40 \\
160 \\
\end{tabular} & $\begin{array}{l}0 \\
0 \\
\end{array}$ \\
\hline Background & $\begin{array}{l}\mathrm{HB} \\
\mathrm{LW} \\
\end{array}$ & \begin{tabular}{|l|} 
DRI Portable \\
DRI Portable \\
\end{tabular} & \begin{tabular}{|l|}
$9 / 15 / 1999$ \\
$9 / 15 / 1999$ \\
\end{tabular} & $\begin{array}{l}1 / 7 / 2000 \\
1 / 7 / 2000 \\
\end{array}$ & \begin{tabular}{|l|} 
Every 6th Day \\
Every 6th Day
\end{tabular} & $\begin{array}{l}24 \\
24 \\
\end{array}$ & $\begin{array}{l}20 \\
20\end{array}$ & $\begin{array}{l}0 \\
0 \\
\end{array}$ \\
\hline $\begin{array}{l}\begin{array}{l}\text { Intensive } \\
\text { (winter) }\end{array} \\
\end{array}$ & $\begin{array}{l}\mathrm{HB} \\
\mathrm{LW}\end{array}$ & $\begin{array}{l}\text { DRI Portable } \\
\text { DRI Portable }\end{array}$ & $\begin{array}{l}1 / 12 / 2000 \\
1 / 12 / 2000\end{array}$ & $\begin{array}{l}2 / 18 / 2000 \\
2 / 18 / 2000\end{array}$ & $\begin{array}{l}\text { Once per day } \\
4 \text { times per day }\end{array}$ & $\begin{array}{l}24 \\
6\end{array}$ & \begin{tabular}{|l|}
38 \\
152 \\
\end{tabular} & $\begin{array}{l}0 \\
0\end{array}$ \\
\hline Background & $\begin{array}{l}\text { HB } \\
\text { LW }\end{array}$ & $\begin{array}{l}\text { DRI Portable } \\
\text { DRI Portable }\end{array}$ & $\begin{array}{l}2 / 24 / 2000 \\
2 / 24 / 2000 \\
\end{array}$ & $\begin{array}{l}7 / 11 / 2000 \\
7 / 11 / 2000 \\
\end{array}$ & $\begin{array}{l}\text { Every 6th Day } \\
\text { Every 6th Day }\end{array}$ & $\begin{array}{l}24 \\
24\end{array}$ & $\begin{array}{l}24 \\
24\end{array}$ & $\begin{array}{l}0 \\
0 \\
\end{array}$ \\
\hline \begin{tabular}{|l}
$\begin{array}{l}\text { Intensive } \\
\text { (summer) }\end{array}$ \\
\end{tabular} & $\begin{array}{l}\text { HB } \\
\text { LW } \\
\end{array}$ & \begin{tabular}{|l|} 
DRI Portable \\
DRI Portable
\end{tabular} & $\begin{array}{l}7 / 17 / 2000 \\
7 / 17 / 2000 \\
\end{array}$ & $\begin{array}{l}8 / 24 / 2000 \\
8 / 25 / 2000 \\
\end{array}$ & \begin{tabular}{|l} 
Once per day \\
4 times per day
\end{tabular} & $\begin{array}{l}24 \\
6 \\
\end{array}$ & $\begin{array}{l}39 \\
160 \\
\end{array}$ & $\begin{array}{l}0 \\
0 \\
\end{array}$ \\
\hline Background & $\begin{array}{l}\mathrm{HB} \\
\mathrm{LW} \\
\end{array}$ & \begin{tabular}{|l|} 
DRI Portable \\
DRI Portable
\end{tabular} & $\begin{array}{l}8 / 28 / 2000 \\
8 / 28 / 2000 \\
\end{array}$ & $\begin{array}{l}6 / 24 / 2001 \\
6 / 24 / 2001 \\
\end{array}$ & \begin{tabular}{|l} 
Every 6th Day \\
Every 6th Day
\end{tabular} & $\begin{array}{l}24 \\
24 \\
\end{array}$ & $\begin{array}{l}51 \\
51\end{array}$ & $\begin{array}{l}0 \\
0 \\
\end{array}$ \\
\hline $\begin{array}{l}\begin{array}{l}\text { Intensive } \\
\text { (summer) }\end{array} \\
\end{array}$ & $\begin{array}{l}\mathrm{HB} \\
\mathrm{LW} \\
\end{array}$ & \begin{tabular}{|l|} 
DRI Portable \\
DRI Portable
\end{tabular} & \begin{tabular}{|l|}
$6 / 30 / 2001$ \\
$6 / 30 / 2001$ \\
\end{tabular} & $\begin{array}{l}8 / 8 / 2001 \\
8 / 8 / 2001 \\
\end{array}$ & \begin{tabular}{|l|} 
Once per day \\
4 times per day \\
\end{tabular} & \begin{tabular}{|l|}
24 \\
6 \\
\end{tabular} & \begin{tabular}{|l|}
40 \\
160 \\
\end{tabular} & $\begin{array}{l}0 \\
0 \\
\end{array}$ \\
\hline \begin{tabular}{|l}
$\begin{array}{l}\text { Intensive } \\
\text { (winter) }\end{array}$ \\
\end{tabular} & $\begin{array}{l}\text { HB } \\
\text { LW }\end{array}$ & $\begin{array}{l}\text { DRI Portable } \\
\text { DRI Portable }\end{array}$ & $\begin{array}{l}1 / 2 / 2002 \\
1 / 2 / 2002 \\
\end{array}$ & $\begin{array}{l}1 / 22 / 2002 \\
1 / 22 / 2002 \\
\end{array}$ & $\begin{array}{l}\text { Once per day } \\
\text { Once per day }\end{array}$ & $\begin{array}{l}24 \\
24\end{array}$ & $\begin{array}{l}21 \\
21\end{array}$ & $\begin{array}{l}0 \\
0 \\
\end{array}$ \\
\hline \begin{tabular}{|l|}
$\begin{array}{l}\text { Intensive } \\
\text { (fall \& winter) }\end{array}$ \\
\end{tabular} & $\begin{array}{l}\mathrm{HB} \\
\mathrm{LW} \\
\end{array}$ & \begin{tabular}{|l|} 
DRI Portable \\
DRI Portable \\
\end{tabular} & \begin{tabular}{|l|}
$10 / 1 / 2002$ \\
$10 / 1 / 2002$ \\
\end{tabular} & $\begin{array}{l}2 / 28 / 2003 \\
2 / 28 / 2003 \\
\end{array}$ & $\begin{array}{l}\text { Once per day } \\
\text { Once per day }\end{array}$ & $\begin{array}{l}24 \\
24 \\
\end{array}$ & $\begin{array}{l}0 \\
0\end{array}$ & $\begin{array}{l}0 \\
0 \\
\end{array}$ \\
\hline
\end{tabular}

*: $\quad$ Excludes Field Blanks $\quad$ **: $\quad$ Excludes Field and Laboratory Blanks 


\section{U.S. DEPARTMENT OF ENERGY \\ NATIONAL ENERGY TECHNOLOGY LABORATORY - PITTSBURGH, PA SEMI-ANNUAL TECHNICAL PROGRESS REPORT OCTOBER 1, 2003 THROUGH MARCH 31, 2004}

TABLE 7

CURRENT DATA STATUS SUMMARY FOR THE ATHENS (AT) SITE

\begin{tabular}{|c|c|c|c|c|c|c|c|c|}
\hline $\begin{array}{l}\text { Constituent } \\
\text { of Concern }\end{array}$ & $\begin{array}{l}\text { Measurement } \\
\text { Technique }\end{array}$ & Data Type & \begin{tabular}{|l} 
Data \\
Collected
\end{tabular} & \begin{tabular}{|l} 
Data \\
Provider
\end{tabular} & \begin{tabular}{|l} 
Data \\
Obtained \\
by ATS \\
\end{tabular} & \begin{tabular}{|l} 
Data \\
Validated \\
by Provider \\
\end{tabular} & \begin{tabular}{|l} 
Data \\
Filtering \\
Status \# \\
\end{tabular} & Notes \\
\hline $\mathrm{PM}_{2.5}$ & $\begin{array}{l}\text { DRI SFS } \\
\text { R\&P FRM } \\
\text { R\&P TEOM } \\
\text { Met One SASS } \\
\text { Anderson SFS }\end{array}$ & $\begin{array}{l}\text { Integrated } * \\
\text { Integrated } * \\
\text { Real-Time } * * \\
\text { Integrated } * \\
\text { Integrated } *\end{array}$ & $\begin{array}{l}\text { No } \\
\text { No } \\
\text { No } \\
\text { Yes } \\
\text { Yes }\end{array}$ & $\begin{array}{c}--- \\
--- \\
--- \\
\text { LabNet } \\
\text { OH EPA }\end{array}$ & $\begin{array}{l}--- \\
--- \\
--- \\
\text { Yes } \\
\text { No }\end{array}$ & $\begin{array}{c}--- \\
--- \\
--- \\
\text { Yes } \\
---\end{array}$ & $\begin{array}{c}--- \\
--- \\
--- \\
\text { In Progress } \\
---\end{array}$ & $\begin{array}{c}--- \\
--- \\
\text { Action item } \\
\text { ATS to request data }\end{array}$ \\
\hline $\mathrm{PM}_{10}$ & $\begin{array}{l}\text { DRI SFS } \\
\text { R\&P TEOM } \\
\text { Anderson Hi-Vol }\end{array}$ & $\begin{array}{l}\text { Integrated } * \\
\text { Real-Time ** } \\
\text { Integrated } *\end{array}$ & $\begin{array}{l}\text { No } \\
\text { No } \\
\text { Yes }\end{array}$ & $\begin{array}{c}--- \\
--- \\
\text { OH EPA }\end{array}$ & $\begin{array}{l}--- \\
--- \\
\text { No }\end{array}$ & $\begin{array}{l}--- \\
--- \\
---\end{array}$ & $\begin{array}{l}--- \\
--- \\
---\end{array}$ & ATS to request data \\
\hline $\mathrm{HNO}_{3}$ & DRI SGS TP & Integrated * & No & --- & --- & --- & --- & --- \\
\hline $\mathrm{NH}_{3}$ & DRI SGS PM 2.5 & Integrated * & No & --- & --- & --- & --- & --- \\
\hline Particle Size & DRI Portable & Integrated * & No & --- & --- & --- & --- & --- \\
\hline Ozone $\left(\mathrm{O}_{3}\right)$ & Continuous Analyzer & Real-Time ** & No & --- & --- & --- & --- & --- \\
\hline Nitrogen Oxides $\left(\mathrm{NO}_{\mathrm{x}}\right)$ & Continuous Analyzer & Real-Time $* *$ & No & --- & --- & --- & --- & --- \\
\hline Sulfur Dioxide $\left(\mathrm{SO}_{2}\right)$ & Continuous Analyzer & Real-Time ** & No & --- & --- & --- & --- & --- \\
\hline Carbon Monoxide (CO) & Continuous Analyzer & Real-Time $* *$ & No & --- & --- & --- & --- & --- \\
\hline Wind Speed / Direction & Continuous Analyzer & Real-Time $* *$ & No & --- & --- & --- & --- & --- \\
\hline Ambient Temperature & Continuous Analyzer & Real-Time $* *$ & No & --- & --- & --- & --- & --- \\
\hline Relative Humidity & Continuous Analyzer & Real-Time $* *$ & No & --- & --- & --- & --- & --- \\
\hline Solar Radiation & Continuous Analyzer & Real-Time ** & No & --- & --- & --- & --- & --- \\
\hline Precipitation Depth & Continuous Analyzer & Real-Time ** & No & --- & --- & --- & --- & --- \\
\hline
\end{tabular}

$\begin{array}{ll}\begin{array}{ll}\text { Legend } \\ \text { DRI }\end{array} & \begin{array}{l}\text { Desert Research Institute } \\ \text { SFS }\end{array} \\ \text { SGS TP } & \begin{array}{l}\text { Sequential Filter Sampler } \\ \text { Sequential Gas Sampler with } \\ \text { Total Particulate Matter Inlet Particle Sizer } \\ \text { SGS PM2.5 }\end{array} \\ & \text { Sequential Gas Sampler with } \\ \text { PM2.5 Inlet Particle Sizer } \\ \text { Anderson } & \text { Filter Sampler with PM2.5 Inlet Particle Sizer } \\ \text { OU } & \text { Sierra (Thermal) Anderson Instruments } \\ \text { LabNet } & \text { Ohio University } \\ & \text { Chester LabNet }\end{array}$

R\&P Rupprecht \& Patashnick Co., Inc.

FRM Federal Reference Method

Hi-Vol High volume air sampler

Met One Met One Instruments, Inc.

TEOM Tapered Element Oscillating Microbalance - Series 1400a

SASS Spiral Aerosol Speciation Sampler

* Over time

** Continuous

\# $\quad$ Performed by ATS - Goal is to develop a final data set that will be utilized for the data analyses and interpretation 


\section{U.S. DEPARTMENT OF ENERGY \\ NATIONAL ENERGY TECHNOLOGY LABORATORY - PITTSBURGH, PA SEMI-ANNUAL TECHNICAL PROGRESS REPORT \\ OCTOBER 1, 2003 THROUGH MARCH 31, 2004}

TABLE 8

CURRENT DATA STATUS SUMMARY FOR THE HOLBROOK (HB) SITE

\begin{tabular}{|c|c|c|c|c|c|c|c|c|}
\hline $\begin{array}{l}\text { Constituent } \\
\text { of Concern }\end{array}$ & $\begin{array}{l}\text { Measurement } \\
\text { Technique }\end{array}$ & Data Type & \begin{tabular}{|l} 
Data \\
Collected
\end{tabular} & \begin{tabular}{|l} 
Data \\
Provider
\end{tabular} & $\begin{array}{l}\text { Data } \\
\text { Obtained } \\
\text { by ATS } \\
\end{array}$ & \begin{tabular}{|l|} 
Data \\
Validated \\
by Provider \\
\end{tabular} & \begin{tabular}{|l} 
Data \\
Filtering \\
Status \# \\
\end{tabular} & Notes \\
\hline $\mathrm{PM}_{2.5}$ & $\begin{array}{l}\text { DRI SFS } \\
\text { R\&P FRM } \\
\text { R\&P TEOM } \\
\text { Met One SASS } \\
\text { Anderson SFS }\end{array}$ & \begin{tabular}{|l|} 
Integrated $*$ \\
Integrated $*$ \\
Real-Time ** \\
Integrated $*$ \\
Integrated $*$
\end{tabular} & $\begin{array}{l}\text { Yes } \\
\text { Yes } \\
\text { Yes } \\
\text { No } \\
\text { No }\end{array}$ & $\begin{array}{l}\text { DRI } \\
\text { DRI } \\
\text { ATS } \\
--- \\
---\end{array}$ & $\begin{array}{l}\text { Yes } \\
\text { Yes } \\
\text { Yes } \\
--- \\
---\end{array}$ & $\begin{array}{l}\text { Yes } \\
\text { Yes } \\
\text { No } \\
--- \\
---\end{array}$ & $\begin{array}{c}\text { Partially complete } \\
\text { Partially complete } \\
\text { In Progress } \\
--- \\
---\end{array}$ & $\begin{array}{l}\text { Action item } \\
\text { Action item } \\
\text { Action item } \\
--- \\
---\end{array}$ \\
\hline $\mathrm{PM}_{10}$ & $\begin{array}{l}\text { DRI SFS } \\
\text { R\&P TEOM } \\
\text { Anderson Hi-Vol }\end{array}$ & $\begin{array}{l}\text { Integrated } * \\
\text { Real-Time ** } \\
\text { Integrated } *\end{array}$ & $\begin{array}{l}\text { Yes } \\
\text { No } \\
\text { No }\end{array}$ & $\begin{array}{l}\text { DRI } \\
\text { ATS } \\
---\end{array}$ & $\begin{array}{l}\text { Yes } \\
\text { Yes } \\
---\end{array}$ & $\begin{array}{l}\text { Yes } \\
\text { No } \\
---\end{array}$ & $\begin{array}{c}\text { Partially complete } \\
\text { Not initiated } \\
---\end{array}$ & $\begin{array}{l}\text { Action item } \\
\text { Action item } \\
---\end{array}$ \\
\hline $\mathrm{HNO}_{3}$ & DRI SGS TP & Integrated * & Yes & DRI & Yes & Yes & In Progress & Action item \\
\hline $\mathrm{NH}_{3}$ & DRI SGS PM PM.5 & Integrated * & Yes & DRI & Yes & Yes & In Progress & Action item \\
\hline Particle Size & DRI Portable & Integrated * & Yes & DRI & No & --- & --- & No samples analyzed \\
\hline Ozone $\left(\mathrm{O}_{3}\right)$ & Continuous Analyzer & Real-Time $* *$ & Yes & PA DEP & Yes & Yes & In Progress & Action item \\
\hline Nitrogen Oxides $\left(\mathrm{NO}_{\mathrm{x}}\right)$ & Continuous Analyzer & Real-Time ** & Yes & PA DEP & Yes & No & In Progress & ATS to validate data \\
\hline Sulfur Dioxide $\left(\mathrm{SO}_{2}\right)$ & Continuous Analyzer & Real-Time $* *$ & Yes & PA DEP & Yes & Yes & In Progress & Action item \\
\hline Carbon Monoxide (CO) & Continuous Analyzer & Real-Time ** & Yes & PA DEP & Yes & Yes & In Progress & Action item \\
\hline Wind Speed / Direction & Continuous Analyzer & Real-Time $* *$ & Yes & PA DEP & Yes & Yes & In Progress & Action item \\
\hline Ambient Temperature & Continuous Analyzer & Real-Time ** & Yes & PA DEP & Yes & Yes & In Progress & Action item \\
\hline Relative Humidity & Continuous Analyzer & Real-Time ** & Yes & PA DEP & Yes & Yes & In Progress & Action item \\
\hline Solar Radiation & Continuous Analyzer & Real-Time $* *$ & No & --- & --- & --- & --- & --- \\
\hline Precipitation Depth & Continuous Analyzer & Real-Time $* *$ & No & --- & --- & --- & --- & --- \\
\hline
\end{tabular}

$\begin{array}{ll}\begin{array}{ll}\text { Legend } \\ \text { DRI }\end{array} & \begin{array}{l}\text { Desert Research Institute } \\ \text { SFS }\end{array} \\ \text { SGS TP } & \text { Sequential Filter Sampler } \\ & \text { Sequential Gas Sampler with } \\ \text { Total Particulate Matter Inlet Particle Sizer } & \text { Sequential Gas Sampler with } \\ \text { SGS PM2.5 } & \text { PM2.5 Inlet Particle Sizer } \\ \text { Portable } & \text { Filter Sampler with PM2.5 Inlet Particle Sizer } \\ \text { Anderson } & \text { Sierra (Thermal) Anderson Instruments } \\ \text { OU } & \text { Ohio University } \\ \text { LabNet } & \text { Chester LabNet }\end{array}$

R\&P Rupprecht \& Patashnick Co., Inc.

FRM Federal Reference Method

Hi-Vol High volume air sampler

Met One Met One Instruments, Inc.

TEOM Tapered Element Oscillating Microbalance - Series 1400a

SASS Spiral Aerosol Speciation Sampler

* Over time

** $\quad$ Continuous

\# $\quad$ Performed by ATS - Goal is to develop a final data set that will be utilized for the data analyses and interpretation 


\section{U.S. DEPARTMENT OF ENERGY \\ NATIONAL ENERGY TECHNOLOGY LABORATORY - PITTSBURGH, PA SEMI-ANNUAL TECHNICAL PROGRESS REPORT OCTOBER 1, 2003 THROUGH MARCH 31, 2004}

TABLE 9

CURRENT DATA STATUS SUMMARY FOR THE LAWRENCEVILLE (LW) SITE

\begin{tabular}{|c|c|c|c|c|c|c|c|c|}
\hline $\begin{array}{l}\text { Constituent } \\
\text { of Concern }\end{array}$ & $\begin{array}{l}\text { Measurement } \\
\text { Technique }\end{array}$ & Data Type & \begin{tabular}{|l} 
Data \\
Collected \\
\end{tabular} & \begin{tabular}{|l} 
Data \\
Provider
\end{tabular} & $\begin{array}{l}\text { Data } \\
\text { Obtained } \\
\text { by } \boldsymbol{A T S} \\
\end{array}$ & \begin{tabular}{|l|} 
Data \\
Validated \\
by Provider \\
\end{tabular} & \begin{tabular}{|l} 
Data \\
Filtering \\
Status \# \\
\end{tabular} & Notes \\
\hline $\mathrm{PM}_{2.5}$ & $\begin{array}{l}\text { DRI SFS } \\
\text { R\&P FRM } \\
\text { R\&P TEOM } \\
\text { Met One SASS } \\
\text { Anderson SFS }\end{array}$ & $\begin{array}{l}\text { Integrated * } \\
\text { Integrated * } \\
\text { Real-Time ** } \\
\text { Integrated * } \\
\text { Integrated * }\end{array}$ & $\begin{array}{l}\text { Yes } \\
\text { Yes } \\
\text { Yes } \\
\text { No } \\
\text { No }\end{array}$ & $\begin{array}{c}\text { DRI } \\
\text { DRI } \\
\text { ATS } \\
--- \\
---\end{array}$ & $\begin{array}{l}\text { Yes } \\
\text { Yes } \\
\text { Yes } \\
--- \\
---\end{array}$ & $\begin{array}{l}\text { Yes } \\
\text { Yes } \\
\text { No } \\
--- \\
---\end{array}$ & \begin{tabular}{|c} 
Partially complete \\
Partially complete \\
In Progress \\
--- \\
---
\end{tabular} & $\begin{array}{l}\text { Action item } \\
\text { Action item } \\
\text { Action item } \\
--- \\
---\end{array}$ \\
\hline $\mathrm{PM}_{10}$ & $\begin{array}{l}\text { DRI SFS } \\
\text { R\&P TEOM } \\
\text { Anderson Hi-Vol }\end{array}$ & $\begin{array}{l}\text { Integrated } * \\
\text { Real-Time ** } \\
\text { Integrated } *\end{array}$ & $\begin{array}{l}\text { Yes } \\
\text { Yes } \\
\text { No }\end{array}$ & $\begin{array}{c}\text { DRI } \\
\text { ATS } \\
---\end{array}$ & $\begin{array}{l}\text { Yes } \\
\text { Yes } \\
---\end{array}$ & $\begin{array}{l}\text { Yes } \\
\text { No } \\
---\end{array}$ & \begin{tabular}{|c} 
Partially complete \\
In Progress \\
---
\end{tabular} & $\begin{array}{l}\text { Action item } \\
\text { Action item } \\
\text {--- }\end{array}$ \\
\hline $\mathrm{HNO}_{3}$ & DRI SGS TP & Integrated * & Yes & DRI & Yes & Yes & In Progress & Action item \\
\hline $\mathrm{NH}_{3}$ & DRI SGS PM 2.5 & Integrated * & Yes & DRI & Yes & Yes & In Progress & Action item \\
\hline Particle Size & DRI Portable & Integrated * & Yes & DRI & No & --- & --- & No samples analyzed \\
\hline Ozone $\left(\mathrm{O}_{3}\right)$ & Continuous Analyzer & Real-Time $* *$ & Yes & ACHD & Yes & Yes & In Progress & Action item \\
\hline Nitrogen Oxides $\left(\mathrm{NO}_{\mathrm{x}}\right)$ & Continuous Analyzer & Real-Time $* *$ & Yes & ACHD & Yes & No & In Progress & Action item \\
\hline Sulfur Dioxide $\left(\mathrm{SO}_{2}\right)$ & Continuous Analyzer & Real-Time $* *$ & Yes & ATS & Yes & No & In Progress & $\boldsymbol{A T S}$ to validate data \\
\hline Carbon Monoxide (CO) & Continuous Analyzer & Real-Time $* *$ & No & ACHD & Yes & Yes & In Progress & Action item \\
\hline Wind Speed / Direction & Continuous Analyzer & Real-Time $* *$ & Yes & ATS & Yes & Yes & In Progress & $\boldsymbol{A T S}$ to validate data \\
\hline Ambient Temperature & Continuous Analyzer & Real-Time ** & Yes & ATS & Yes & Yes & In Progress & $\boldsymbol{A T S}$ to validate data \\
\hline Relative Humidity & Continuous Analyzer & Real-Time $* *$ & Yes & ATS & Yes & Yes & In Progress & $\boldsymbol{A T S}$ to validate data \\
\hline Solar Radiation & Continuous Analyzer & Real-Time $* *$ & Yes & ATS & Yes & Yes & In Progress & $\boldsymbol{A T S}$ to validate data \\
\hline Precipitation Depth & Continuous Analyzer & Real-Time $* *$ & Yes & ATS & Yes & Yes & In Progress & $\boldsymbol{A T S}$ to validate data \\
\hline
\end{tabular}

$\begin{array}{ll}\begin{array}{ll}\text { Legend } \\ \text { DRI }\end{array} & \text { Desert Research Institute } \\ \text { SFS } & \text { Sequential Filter Sampler } \\ \text { SGS TP } & \text { Sequential Gas Sampler with } \\ & \text { Total Particulate Matter Inlet Particle Sizer } \\ \text { SGS PM2.5 } & \text { Sequential Gas Sampler with } \\ & \text { PM2.5 Inlet Particle Sizer } \\ \text { Portable } & \text { Filter Sampler with PM2.5 Inlet Particle Sizer } \\ \text { Anderson } & \text { Sierra (Thermal) Anderson Instruments } \\ \text { OU } & \text { Ohio University } \\ \text { LabNet } & \text { Chester LabNet }\end{array}$

R\&P Rupprecht \& Patashnick Co., Inc.

FRM Federal Reference Method

Hi-Vol High volume air sampler

Met One Met One Instruments, Inc.

TEOM Tapered Element Oscillating Microbalance - Series 1400a

SASS Spiral Aerosol Speciation Sampler

* Over time

** Continuous

\# $\quad$ Performed by $\boldsymbol{A T S}$ - Goal is to develop a final data set that will be utilized for the data analyses and interpretation 


\section{U.S. DEPARTMENT OF ENERGY \\ NATIONAL ENERGY TECHNOLOGY LABORATORY - PITTSBURGH, PA SEMI-ANNUAL TECHNICAL PROGRESS REPORT \\ OCTOBER 1, 2003 THROUGH MARCH 31, 2004}

TABLE 10

CURRENT DATA STATUS SUMMARY FOR THE MORGANTOWN (MO) SITE

\begin{tabular}{|c|c|c|c|c|c|c|c|c|}
\hline $\begin{array}{l}\text { Constituent } \\
\text { of Concern }\end{array}$ & $\begin{array}{l}\text { Measurement } \\
\text { Technique }\end{array}$ & Data Type & \begin{tabular}{|l} 
Data \\
Collected
\end{tabular} & \begin{tabular}{|l} 
Data \\
Provider
\end{tabular} & $\begin{array}{l}\text { Data } \\
\text { Obtained } \\
\text { by ATS }\end{array}$ & \begin{tabular}{|l|} 
Data \\
Validated \\
by Provider \\
\end{tabular} & \begin{tabular}{|l} 
Data \\
Filtering \\
Status \# \\
\end{tabular} & Notes \\
\hline $\mathrm{PM}_{2.5}$ & $\begin{array}{l}\text { DRI SFS } \\
\text { R\&P FRM } \\
\text { R\&P TEOM } \\
\text { Met One SASS } \\
\text { Anderson SFS }\end{array}$ & $\begin{array}{l}\text { Integrated } * \\
\text { Integrated } * \\
\text { Real-Time } * * \\
\text { Integrated } * \\
\text { Integrated } *\end{array}$ & $\begin{array}{l}\text { Yes } \\
\text { Yes } \\
\text { No } \\
\text { No } \\
\text { No }\end{array}$ & $\begin{array}{c}\text { DRI } \\
\text { WV DEP } \\
--- \\
--- \\
---\end{array}$ & $\begin{array}{l}\text { Yes } \\
\text { No } \\
-- \\
--- \\
---\end{array}$ & $\begin{array}{l}\text { Yes } \\
--- \\
--- \\
--- \\
---\end{array}$ & \begin{tabular}{|c|} 
Partially complete \\
--- \\
--- \\
--- \\
---
\end{tabular} & $\begin{array}{c}\text { Action item } \\
\text { ATS to request data } \\
--- \\
--- \\
---\end{array}$ \\
\hline $\mathrm{PM}_{10}$ & $\begin{array}{l}\text { DRI SFS } \\
\text { R\&P TEOM } \\
\text { Anderson Hi-Vol }\end{array}$ & $\begin{array}{l}\text { Integrated } * \\
\text { Real-Time } * * \\
\text { Integrated } *\end{array}$ & $\begin{array}{l}\text { No } \\
\text { No } \\
\text { Yes }\end{array}$ & $\begin{array}{c}--- \\
--- \\
\text { WV DEP }\end{array}$ & $\begin{array}{l}--- \\
--- \\
\text { No }\end{array}$ & $\begin{array}{l}--- \\
--- \\
--\end{array}$ & $\begin{array}{l}--- \\
--- \\
---\end{array}$ & ATS to request data \\
\hline $\mathrm{HNO}_{3}$ & DRI SGS TP & Integrated * & No & --- & --- & --- & --- & --- \\
\hline $\mathrm{NH}_{3}$ & DRI SGS PM 2.5 & Integrated * & No & --- & --- & --- & --- & --- \\
\hline Particle Size & DRI Portable & Integrated * & No & --- & --- & --- & --- & --- \\
\hline Ozone $\left(\mathrm{O}_{3}\right)$ & Continuous Analyzer & Real-Time ** & Yes & WV DEP & No & --- & --- & ATS to request data \\
\hline Nitrogen Oxides $\left(\mathrm{NO}_{\mathrm{x}}\right)$ & Continuous Analyzer & Real-Time ** & No & --- & --- & --- & --- & --- \\
\hline Sulfur Dioxide $\left(\mathrm{SO}_{2}\right)$ & Continuous Analyzer & Real-Time ** & Yes & WV DEP & No & --- & --- & ATS to request data \\
\hline Carbon Monoxide (CO) & Continuous Analyzer & Real-Time ** & No & --- & --- & --- & --- & --- \\
\hline Wind Speed / Direction & Continuous Analyzer & Real-Time $* *$ & No & --- & --- & --- & --- & --- \\
\hline Ambient Temperature & Continuous Analyzer & Real-Time $* *$ & No & --- & --- & --- & --- & --- \\
\hline Relative Humidity & Continuous Analyzer & Real-Time ** & No & --- & --- & --- & --- & --- \\
\hline Solar Radiation & Continuous Analyzer & Real-Time ** & No & --- & --- & --- & --- & --- \\
\hline Precipitation Depth & Continuous Analyzer & Real-Time $* *$ & No & --- & --- & --- & --- & --- \\
\hline
\end{tabular}

$\begin{array}{ll}\begin{array}{ll}\text { Legend } \\ \text { DRI }\end{array} & \begin{array}{l}\text { Desert Research Institute } \\ \text { SFS }\end{array} \\ \text { SGS TP } & \begin{array}{l}\text { Sequential Filter Sampler } \\ \text { Sequential Gas Sampler with } \\ \text { Total Particulate Matter Inlet Particle Sizer } \\ \text { SGS PM2.5 }\end{array} \\ & \text { Sequential Gas Sampler with } \\ \text { PM2.5 Inlet Particle Sizer } \\ \text { Anderson } & \text { Filter Sampler with PM2.5 Inlet Particle Sizer } \\ \text { OU } & \text { Sierra (Thermal) Anderson Instruments } \\ \text { LabNet } & \text { Ohio University } \\ & \text { Chester LabNet }\end{array}$

R\&P Rupprecht \& Patashnick Co., Inc.

FRM Federal Reference Method

Hi-Vol High volume air sampler

Met One Met One Instruments, Inc.

TEOM Tapered Element Oscillating Microbalance - Series 1400a

SASS Spiral Aerosol Speciation Sampler

* Over time

** $\quad$ Continuous

\# $\quad$ Performed by ATS - Goal is to develop a final data set that will be utilized for the data analyses and interpretation 
COMPARATIVE EVALUATION OF AMBIENT FINE PARTICULATE MATTER (PM2.5) DATA OBTAINED FROM URBAN AND RURAL MONITORING SITES ALONG THE UPPER OHIO RIVER VALLEY SEMI-ANNUAL TECHNICAL PROGRESS REPORT OCTOBER 1, 2003 THROUGH MARCH 31, 2004

Submitted to:

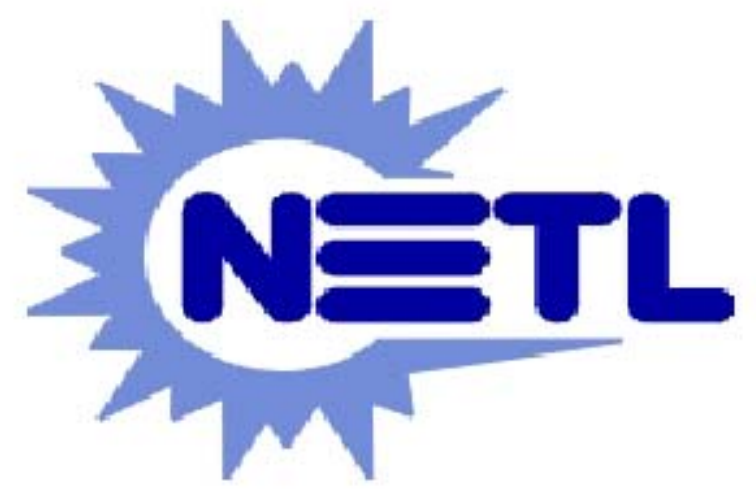

U. S. Department of Energy

National Energy Technology Laboratory Pittsburgh, PA 15236

DOE AWARD NUMBER: DE-AC26-98FT40456

\section{APPENDIX A}

Digital Images of the UORVP Air Monitoring Sites

(To be provided) 